\title{
Nitrogen dynamics in the Westerschelde estuary (SW Netherlands) estimated by means of the ecosystem model MOSES
}

\author{
Karline Soetaert \& Peter M. J. Herman \\ Netherlands Institute of Ecology, Vierstraat 28, NL-4401 EA Yerseke, The Netherlands \\ Key words: Nitrogen, budget, nitrification, denitrification, Westerschelde, estuary

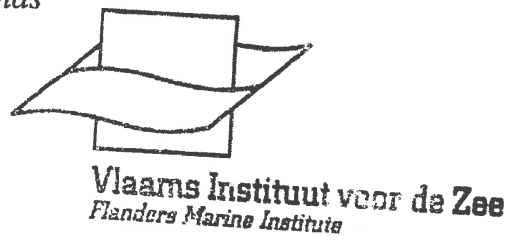

\begin{abstract}
A tentative nitrogen budget for the Westerschelde (SW Netherlands) is constructed by means of a simulation model with thirteen spatial compartments. Biochemical and chemical processes in the water column are dynamically modeled; fluxes of dissolved constituents across the water-bottom interface are expressed by means of diagenetic equations.

The model is calibrated on a large amount of observed variables in the estuary (1980-1986) with relatively fine temporal and spatial detail. Additional constraints are imposed by the stoichiometric coupling of carbon, nitrogen and oxygen flows and the required conservation of mass. The model is able to reproduce rather well the observed distributions of nitrate, ammonium, oxygen and Kjeldahl nitrogen both in time and space. Also, model output of biochemical oxygen demand and total organic carbon falls within observed ranges.

By far the most pervasive process in the nitrogen cycle of the estuary is nitrification which mainly takes place in the water column of the upper estuarine part. On average about three times as much nitrate is leaving the estuary at the sea side compared to what enters from the river and from waste discharges. Ammonium on the other hand is consumed much faster (nitrification) than it is regenerated and only about one third of the total import leaves the estuary at the sea side. The budget for detrital nitrogen reveals import from the river, from wastes and from the sea. Phytoplankton uptake of inorganic nitrogen is negligible in the model.

About $21 \%$ of total nitrogen, $33 \%$ of inorganic nitrogen, is removed from the estuary (mainly to the atmosphere through denitrification) and the load of nitrogen net exported to the sea amounts to about 51000 tonnes per year. Total denitrification in our model is lower than what was estimated in the literature from the late seventies, where a nitrogen removal up to $40-50 \%$ of the total inorganic load was reported. Part of the differences could be methodological, but inspection of the nutrient profiles that led to these conclusions show them to be different to the ones used in our study. The oxygen deficient zone has moved upstream since the late seventies, entrailing the zone of denitrification into the riverine part of the Schelde. The nitrification process now starts immediately upon entering the estuary.
\end{abstract}

\section{Introduction}

By far the major input of land-derived nutrients into the coastal sea occurs through riverine transport (Billen et al., 1991). On their way to the coastal zone, the nutrients have to pass through estuaries where both the quantity and the quality of the constituents is altered. The Westerschelde estuary (SW Netherlands) is the last remaining true estuary from the Dutch Delta region and discharges on average about $100 \mathrm{~m}^{3}$ freshwater per second into the Southern Bight of the North Sea (Van Eck \& de Rooij, 1990). At the scale of the entire North Sea ecosystem, the Westerschelde contributes only marginally to nutrient load (Brockmann et al., 1988) but its effect locally is enhanced due to the presence of a residual gyre which elongates the residence time of the water masses near the estuarine mouth (Nihoul \& Ronday, 1975).

The Westerschelde is one of the most polluted estuaries in the world as it receives a substantial amount of 
largely untreated industrial and domestic wastes (Heip, 1988). Thus the estuary has an unusually high load of organic and inorganic substances. Although nitrogen is never limiting phytoplankton growth in the Westerschelde estuary (Kromkamp et al., 1992; Soetaert et al., 1994), it is the limiting macronutrient over most of the North Sea (Brockmann et al., 1991) and the most common blooming species in the North Sea, the nuisant Phaeocystis, is probably nitrogen limited in Belgian coastal waters (Lancelot \& Billen, 1984). As such, the amount of outwelling of nitrogen from the estuary could be important for the degree of coastal eutrophication.

A decade ago, a nitrogen budget for the Westerschelde was constructed by Billen et al. $(1985,1986$, 1988). This budget was based on data from 1975 to 1983. They found that about $40-50 \%$ of the total nitrogen load was removed within the estuary, partly due to denitrification in the anaerobic water column in the most upstream estuarine stretch. Moreover, the authors suggested that restoring higher oxygen content in the river or estuary, without eliminating the inorganic nitrogen load, would reduce denitrification in the water column and thus - paradoxically - tend to increase the nitrogen discharge to the sea.

We have studied the flow and speciation of the various nitrogen species in the Westerschelde estuary by means of an ecosystem simulation model. The aim was to determine the fate and turnover of nutrients entering the estuary and to describe the temporal and spatial patterns of nutrient concentrations and fluxes in the estuary. Estimates are based on data from the years 1980-1986. Our - independently derived - budget is compared to that of Billen et al. $(1985,1986,1988)$ and the results are discussed in the light of estuarine eutrophication.

The modelling effort that is presented here is achieved as part of a project financed by the ministry of transport and public works (The Hague) and as part of the Joint Estuarine Ecosystem Programme sponsored by the European community. This is one of a series of papers describing the ecosystem simulation model of the Westerschelde.

\section{Material and methods}

The ecological MOdel of the Schelde Estuary (hereafter denoted as MOSES) was implemented in the simulation environment SENECA (de Hoop et al., 1993). This modelling package takes care of most routines common to modelling exercises (automatic calibration, sensitivity analysis, numerical integration) and provides easy input-output management. MOSES is a compartmentalized model, describing processes in the pelagic, in the intertidal and in the sublittoral. These zones are subdivided into thirteen spatial compartments. The sublittoral is defined as that part of the bottom in a pelagic compartment that is deeper than the intertidal and less deep than $10 \mathrm{~m}$. The intertidal consists of thirteen distinct morphological units (see Fig. 1).

Transport of dissolved matter is modeled by a constant-volume advective-dispersive finite difference approximation (Thomann \& Mueller, 1987) which has been calibrated on chlorinity data (Soetaert \& Herman, 1995a). Particulate matter is also transported by means of advective and dispersive processes, but net advection at the most seaward compartments is directed into the estuary. This allows for the creation of a turbidity maximum and a seasonal pattern in the concentration of particulate matter (Soetaert \& Herman, 1993). Organic matter is then moved in the model by assuming that it behaves partly dissolved, partly particulate.

The biological processes described in the model are (pelagic and benthic) primary production and feeding, respiration, excretion and physiological and predatory mortality of secondary producers (micro- and mesozooplankton, hyperbenthos, benthic deposit and suspension feeders). MOSES is essentially a carbon-based model with the oxygen and nitrogen cycles linked via stoichiometric equations. For a rationale on the modelling strategy and the other modeled processes, we refer to Soetaert \& Herman (1993), Soetaert et al. (1994) and Soetaert \& Herman (1995b). Part of the data set (waste loads, nutrient concentrations, BOD) was kindly provided by Dr Van Eck and Mr A. Schouwenaar (SAWES, 1991).

\section{Biochemical and physical processes in the water phase}

In what follows, STATE VARIABLES (e.g. concentrations of the various nutrients) are denoted by capital letters, parameters (e.g. rate constants, coefficients) are denoted in italics.

In short, the model simulates the temporal evolution of state variables by integrating their rate of change (denoted as $\mathrm{dX} / \mathrm{dt}$ ) in time. Numerical integration is performed within the simulation package SENECA (de Hoop et al., 1993) by Euler integration with adaptive time step. 
The Netherlands
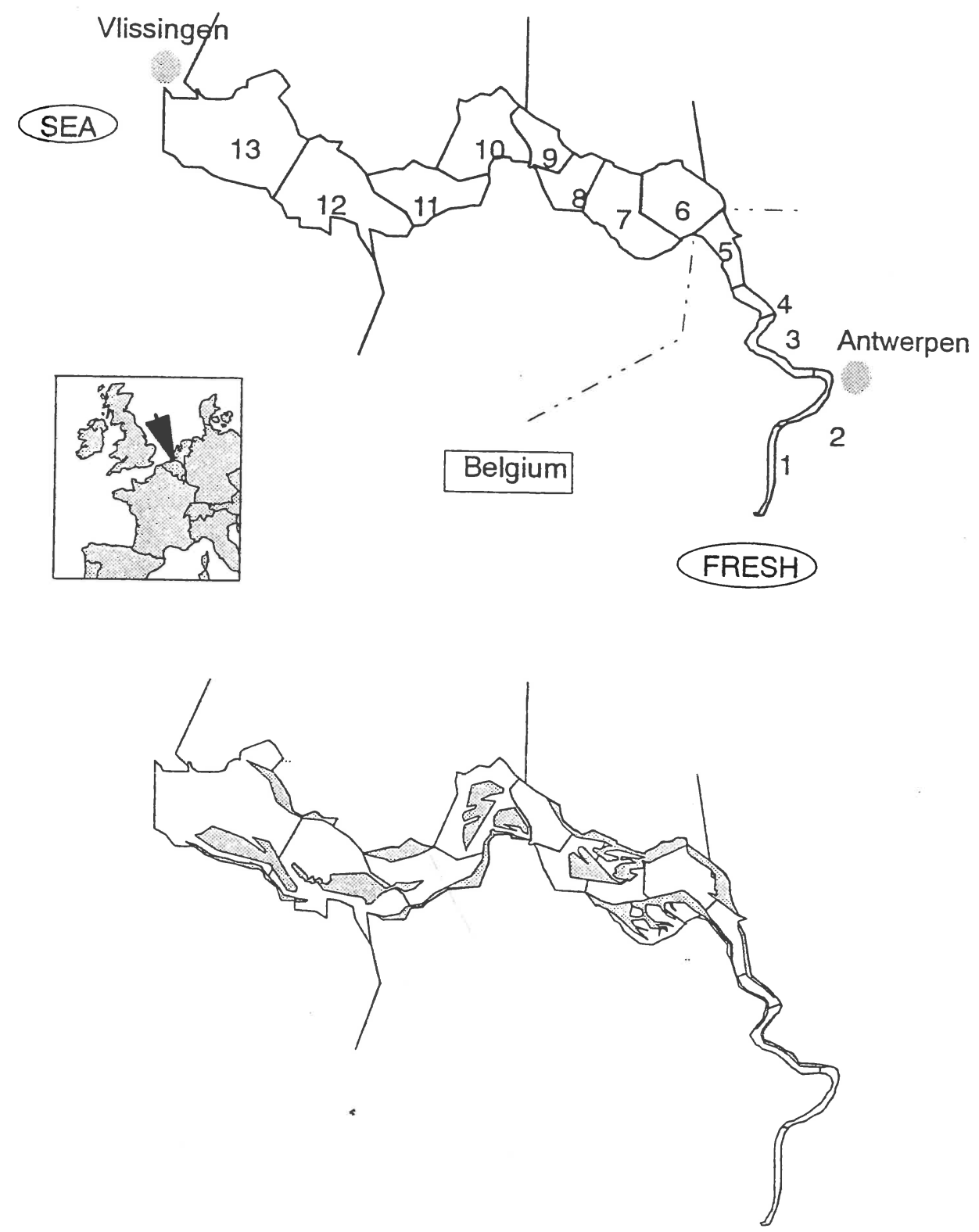

Fig. 1. Spatial compartimentalisation of the Westerschelde estuary. Upper half: pelagic compartments, lower half: intertidal compartments.

State variables (Table 1)

Two dissolved inorganic nitrogen state variables are considered: ammonium $\left(\mathrm{NH}_{4}\right)$ and nitrate + nitrite (NITR). Nitrite and nitrate are combined into one state variable since nitrite is generally rapidly converted to nitrate. Moreover, in the Westerschelde, the nitrite concentration usually is less than $5 \%$ of the total pool. Nitrous oxide and dinitrogen gas, both products of denitrification, are not modeled as these are lost to the atmosphere.

Dissolved oxygen (OX) has a strong impact on the nitrogen cycle as it determines the type of processes (nitrification-denitrification, aerobic degradation) that will take place in the estuary.

The detritus in rivers and estuaries is a complex mixture of biochemicals with oxidation times ranging 
Table 1. State variables of MOSES relevant to the biochemical submodel.

\begin{tabular}{lll}
\hline State variable & Units & Acronym \\
\hline Oxygen & $\mathrm{g} \mathrm{O}_{2} \mathrm{~m}^{-3}$ & $\mathrm{OX}$ \\
Ammonium & $\mathrm{g} \mathrm{N} \mathrm{m}^{-3}$ & $\mathrm{NH} 4$ \\
Nitrate+Nitrite & $\mathrm{g} \mathrm{N} \mathrm{m}^{-3}$ & $\mathrm{NITR}$ \\
Fast-decay detritus & $\mathrm{g} \mathrm{C} \mathrm{m}^{-3}$ & FD \\
Slow-decay detritus & $\mathrm{g} \mathrm{C} \mathrm{m}^{-3}$ & $\mathrm{SD}$ \\
\hline
\end{tabular}

Table 2. Effect of the modeled process on the state variables. ' ++ ' indicates increase, '- -' indicates decrease, ' $/$ ' no effect.

\begin{tabular}{|c|c|c|c|c|c|}
\hline $\begin{array}{l}\text { State variable: } \\
\text { Process: }\end{array}$ & NITR & NH4 & FD & SD & OX \\
\hline Aerobic mineralisation & I & ++ & -- & $\cdots$ & -- \\
\hline \multicolumn{6}{|l|}{ Denitrification/nitrate } \\
\hline reduction & $\cdots$ & ++ & $\cdots$ & -- & 1 \\
\hline Nitrification & ++ & $-\cdot$ & ++ & 1 & -- \\
\hline Aeration & 1 & 1 & 1 & 1 & ++ \\
\hline Waste import & ++ & ++ & ++ & ++ & ++ \\
\hline
\end{tabular}

from hours to thousands of years (Spitzy \& Ittekot, 1991). Although the labile organic matter in natural water is present as a continuum of biodegradabilities and $\mathrm{C} / \mathrm{N}$ content (Garber, 1984), such precision cannot be attained by a simple ecosystem model. Thus, following Lancelot \& Billen (1985) and Billen \& Lancelot (1988), in MOSES two detritus state variables are distinguished, namely slowly and fast decaying detritus (SD and FD) each with its own biodegradabilities (cSDMin resp. cFDMin) and N/C content ( NCrSD resp. $N C r F D$ ). The (arbitrary) distinction between dissolved and particulate organic matter is not made here. Both the slow and fast decaying detritus fractions consist of a dissolved and a particulate phase.

As in many other models (e.g. Klepper, 1989; Di Toro et al., 1971), bacteria are not considered separately in MOSES, but they are included in the detritus fraction.

The modeled processes in the water column are aerobic mineralisation, denitrification, nitrification, aeration and waste import. Their effect on the state variables is summarized in Table 2 . The equations used are given in Table 3. Table 4 explains the variables used to describe rates in these equations, whereas Table 5 gives the value and meaning of the parameters.
'Aerobic mineralization' is modeled as a first-order process with respect to the organic load (Streeter \& Phelps, 1925) (Eqs. 1 and 2, Table 3). The influence of temperature on mineralisation is represented by means of a Q10 function. Oxygen limitation is modeled by means of a hyberbolic relation. The amount of ammonium produced by means of mineralisation relates to the amount of $\mathrm{CO}_{2}$ production through the (fixed) Nitrogen to Carbon ratio of the detritus fraction (Eq. 3, Table 3). Per amount of carbon that is thus converted an amount $\mathrm{OCr}$ of oxygen is consumed (Eq. 4, Table 3).

'Denitrification' is an anaerobic and heterotrophic process, using nitrate and nitrite as an electron acceptor. The products of denitrification are $\mathrm{N}_{2}$ or $\mathrm{N}_{2} \mathrm{O}$ which are lost to the atmosphere. Nitrate reduction can also lead to $\mathrm{NH}_{4}^{+}$formation, especially at high organic matter content and low nitrate concentration. Denitrification is modeled as a first-order kinetic equation with respect to nitrate content. It depends on temperature (Q10 formulation) and is depressed at high oxygen concentrations (hyperbolic relation). The detritus fraction can also become limiting (Dlim) (Seitzinger, 1988 ) and both the availability and the reactivity of the two detritus fractions has to be considered. Dlim is expressed as a Monod equation with half saturation constant $k s D e n D$ (Eq. 5, Table 3). Denitrification rate is given in Eq. 6 (Table 3). For each gram of nitrate reduced, a (fixed) amount $\mathrm{CNrDenit}$ of detritus is converted to $\mathrm{CO}_{2}$. The part of fast and slow detritus that is denitrified is both function of total load and reactivity (Eqs. 7 and 8, Table 3). Carbon to nitrogen stoichiometry is assured with ammonium. During nitrate reduction, nitrate is partly converted into ammonium. The resulting rate of change in ammonium is given in Eq. 9 (Table 3).

'Nitrification' is an aerobic process, usually mediated by two different types of autotrophic bacteria, which obtain energy from oxidation of ammonium to nitrite, followed by the oxidation of nitrite to nitrate. They obtain cell carbon from carbon dioxide. The process depends on temperature (Q10 formulation) and is inhibited in anaerobic conditions (hyperbolic relation). Owing to the slow development of nitrifying bacteria (Billen et al., 1986) there is an upper limit to the rate of nitrification. This was modeled as a hyperbolic relationship with ammonium (Helder \& De Vries, 1983; Somville et al., 1982). The nitrification rate $c N I T R$ is then given by Eq. 10 (Table 3). Being autotrophic, the nitrifying bacteria produce organic carbon from $\mathrm{CO}_{2}$, with a low efficiency (Helder \& de Vries, 1983; 
Table 3. Formulations used for the processes affecting nitrogen in the model. See Table 1 for a list of state variables, Table 4 for a list of variables used in these expressions, Table 5 for a list of parameters. The symbol @ represents all other processes (e.g. transport, uptake or excretion by zooplankton, etc...) affecting the state variables, but not explicitly discussed in this paper. Terms ending on 'Imp' in the differential equations of the state variables denote imports from (lateral) waste loads into the estuary. In several expressions, $\mathrm{T}$ denotes ambient temperature, $\mathrm{T}_{0}$ denotes base temperature at which the basic rate is defined. Expressions are explained in the text.

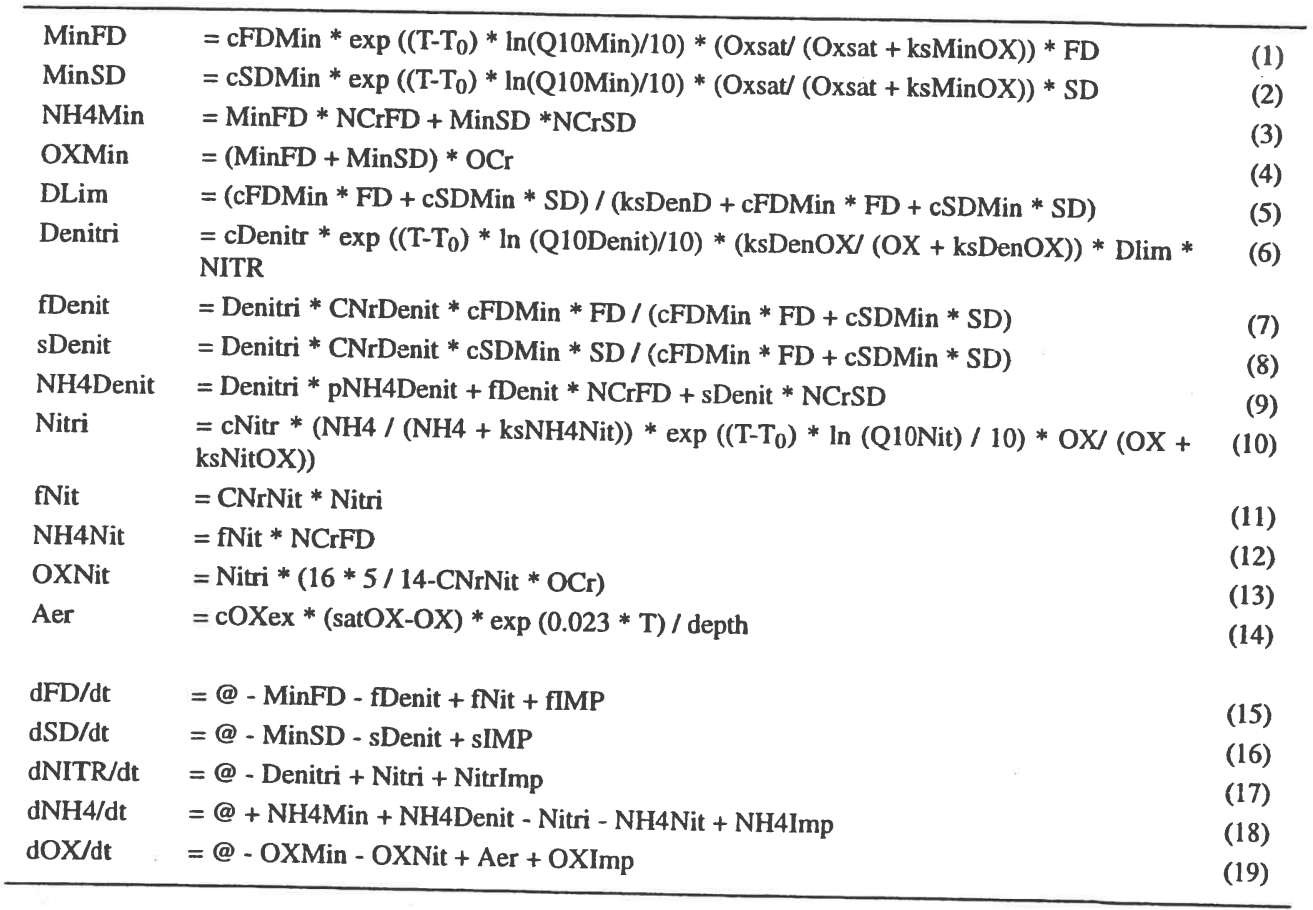

Table 4. List of variables used in the expressions of Table 3.

\begin{tabular}{lll}
\hline Variable & Units & Comments \\
MinFD & $\mathrm{g} \mathrm{C} \mathrm{m}^{-3} \mathrm{~d}^{-1}$ & Aerobic mineralisation rate of fast detritus \\
MinSD & $\mathrm{g} \mathrm{C} \mathrm{m}^{-3} \mathrm{~d}^{-1}$ & Aerobic mineralisation rate of slow detritus \\
NH4Min & $\mathrm{g} \mathrm{N} \mathrm{m}^{-3} \mathrm{~d}^{-1}$ & NH4 production rate in aerobic mineralisation \\
OXMin & $\mathrm{g} \mathrm{O}_{2} \mathrm{~m}^{-3} \mathrm{~d}^{-1}$ & OX consumption rate in aerobic mineralisation \\
DLim & - & Limitation of denitrification by detritus \\
Denitri & $\mathrm{g} \mathrm{N} \mathrm{m}^{-3} \mathrm{~d}^{-1}$ & Denitrification rate \\
fDenit & $\mathrm{g} \mathrm{C} \mathrm{m}^{-3} \mathrm{~d}^{-1}$ & Loss rate of fast detritus in denitrificaiton \\
sDenit & $\mathrm{g} \mathrm{C} \mathrm{m}^{-3} \mathrm{~d}^{-1}$ & Loss rate of slow detritus in denitrification \\
NH4Denit & $\mathrm{g} \mathrm{N} \mathrm{m}^{-3} \mathrm{~d}^{-1}$ & Rate of change in NH4 due to denitrification \\
Nitri & $\mathrm{g} \mathrm{N} \mathrm{m}^{-3} \mathrm{~d}^{-1}$ & Loss rate of NH4 due to nitrification \\
fNit & $\mathrm{g} \mathrm{C} \mathrm{m}^{-3} \mathrm{~d}^{-1}$ & Production rate of fast detritus in nitrification \\
NH4Nit & $\mathrm{g} \mathrm{N} \mathrm{m}^{-3} \mathrm{~d}^{-1}$ & Uptake rate of NH4 for growth of nitrifiers \\
OXNit & $\mathrm{g} \mathrm{O}_{2} \mathrm{~m}^{-3} \mathrm{~d}^{-1}$ & Oxygen consumption rate in nitrification \\
Aer & $\mathrm{g} \mathrm{O}_{2} \mathrm{~m}^{-3} \mathrm{~d}^{-1}$ & Reaeration rate \\
SatOX & $\mathrm{g} \mathrm{O}_{2} \mathrm{~m}^{-3} \mathrm{~d}^{-1}$ & Saturation concentration of oxygen at ambient \\
& & temperature and salinity
\end{tabular}


Table 5. Best parameter values.

\begin{tabular}{|c|c|c|c|}
\hline Parameter & Value & Units & Comment \\
\hline BOD20 & 0.05 & $d^{-1}$ & Biochemical oxygen demand of wastes at $20 \mathrm{dg}$ \\
\hline fdFRSH & 0.7 & - & part of riverine detritus that is fast decaying \\
\hline fdSEA & 0.4 & - & part of seawater detritus that is fast decaying \\
\hline Q10Min & 1.6 & - & Q10 value for aerobic mineralisation \\
\hline KsMinOX & 0.54 & $\mathrm{gO} \mathrm{m}^{-3}$ & monod ct of oxygen limitation aerobic degrad \\
\hline cSDMin & 2.E-3 & $d^{-1}$ & Aerobic degradation of slow detritus at $20 \mathrm{dg}$ \\
\hline cFDMin & 0.11 & $d^{-1}$ & Aerobic degradation of fast detritus at $20 \mathrm{dg}$ \\
\hline $\mathrm{NCrFD}$ & 0.3 & $\mathrm{gN}\left(\mathrm{g} \mathrm{C}^{-1}\right.$ & nitrogen-carbon ratio of fast detritus \\
\hline NCrSD & 0.1 & $\mathrm{gN}\left(\mathrm{g} \mathrm{C}^{-1}\right.$ & nitrogen-carbon ratio of slow detritus \\
\hline $\mathrm{OCr}$ & 2.7 & $\mathrm{~g} \mathrm{O}_{2}\left(\mathrm{~g} \mathrm{C}^{-1}\right.$ & gr Oxygen respired or produced per gram carbon \\
\hline Q10Denit & 1.65 & - & Q10 value for denitrification \\
\hline ksDenOX & 0.7 & $\mathrm{~g} \mathrm{O}_{2} \mathrm{~m}^{-3}$ & monod ct in oxygen limitation denitrification \\
\hline ksDenD & 3.75 & $\mathrm{~g} \mathrm{C} \mathrm{m}^{-3}$ & monod ct in detritus limitation of Denitrif \\
\hline cDenitr & 1. & $g N(g N)^{-1} d^{-1}$ & denitrification rate at 10 degr Celsius \\
\hline CNrDenit & 1.04 & $\mathrm{gC}\left(\mathrm{g} \mathrm{N}^{-1}\right.$ & $\mathrm{g}$ C oxidized per gram $\mathrm{N}$ during denitrification \\
\hline pNH4Den & 0.2 & - & part of NH4 produced during nitrate reduction \\
\hline Q10Nit & 3.37 & - & Q10 value for nitrification \\
\hline ksNitOX & 2.5 & $\mathrm{~g} \mathrm{O}_{2} \mathrm{~m}^{-3}$ & monod ct in oxygen limitation nitrification \\
\hline ksNH4Nit & 9. & $\mathrm{~g} \mathrm{~N} \mathrm{~m}^{-3}$ & monod ct in ammonium limitation nitrification \\
\hline cNitr & 1. & $\mathrm{~g} \mathrm{~N} \mathrm{~d}^{-1}$ & nitrification coefficient at $10 \mathrm{degr}$ Celsius \\
\hline CNrNit & 0.033 & $\mathrm{gC}(\mathrm{g} \mathrm{N})^{-1}$ & gr $\mathrm{C}$ fixed per $\mathrm{g} \mathrm{N}$ during nitrification process \\
\hline cOXex & 1.75 & $\mathrm{~m} \mathrm{~d}^{-1}$ & coefficient for oxygen exchange water-atmosphere \\
\hline
\end{tabular}

Brock \& Madigan, 1991). As bacterial biomass is not modeled as such, the product of nitrification joins the fast decaying detritus part (Eq. 11, Table 3). Stoichiometric equilibrium is assured with ammonium (Eq. 12, Table 3). Nitrification is an oxygen demanding process: per gram nitrogen an amount ONrNit of oxygen is converted. The products of the oxidation of ammonium are water and nitrate and this requires $5 \mathrm{~mol}(16 \times 5$ gram) oxygen per mole (14 gram) nitrogen (Brock \& Madigan, 1991). Incorporating $\mathrm{CO}_{2}$ into fast detritus releases oxygen, according to the fixed factor $O C r$. Thus the rate of change in oxygen, due to nitrification, is given by Eq. 13 (Table 3).

The 'oxygen exchange' between water column and atmosphere is one of the most important sources of oxygen to the water column. It is modelled as in O'Kane (1980) (Eq. 14, Table 3; where satOX is oxygen saturation concentration, calculated from temperature and salinity).

'Waste discharges' of inorganic nitrogen were obtained from the SAWES database (SAWES, 1991). Waste input of organic nitrogen is estimated based on Kjeldahl nitrogen, ammonium and BOD values discharged per day (Biochemical oxygen demand), obtained from SAWES (1991). The total load of carbon was calculated from dayly BOD values according to Thomann \& Mueller (1987). Total organic nitrogen was obtained by substracting ammonium from Kjeldahl nitrogen waste load data. This organic nitrogen waste load was used to partition the carbon wastes into a fast and slow detrital fraction by requiring that the fast and slow detrital fractions in the carbon waste loads have their (fixed) model values $N C r F D$ and $N C r S D$. Import values $\left(\mathrm{g} \mathrm{d}^{-1}\right)$ were divided by the volume of the compartment into which the discharge took place, to calculate rates of change of state variables due to import.

'Boundary conditions' at the freshwater and seawater boundaries have to be specified for those constituents that are transported. For the dissolved nutrients and oxygen, boundary concentrations were available as such and obtained from the SAWES database (SAWES, 1991). The boundary conditions of fast and slow decaying detritus were calculated using Biochemical Oxygen Demand values at the fresh and marine boundary. Calculations were based on the mineraliza- 
tion rates of the detritus fractions in the estuary ( $C F D$ Min, cSDMin) and assuming that a fixed part of imported detritus is fast decaying ( $f d F R S H$, resp. $f d S E A)$. The amount of phytoplankton carbon was substracted to give the total detrital carbon at the boundary.

\section{Benthic-pelagic exchange processes}

As organic matter sediments to the bottom it is degraded by a sequence of oxidants. These reactions promote a flow of dissolved chemicals across the sedimentwater interface (Malcolm \& Stanley, 1982). It has been shown that even extremely idealized diagenetic models can account for the major trends of the behavior of various substances in the sedimentary column (Billen, 1982). For the Westerschelde, we implemented the idealized model of nitrogen recycling as proposed by Lancelot \& Billen (1985). This model was extended to include the exchange of oxygen across the sedimentwater interface (Soetaert \& Herman, 1993).

In the diagenetic model of Lancelot \& Billen (1985) the rate of denitrification, and the release or uptake of nitrate and ammonium from the bottom is calculated from the input of organic matter (consisting of two degradable fractions) to the bottom, from the overlying nitrate and oxygen concentration and from the mixing coefficient of the sediment interstitial and solid phases. The model assumes that nutrient advection due to sediment accumulation is negligible. It considers an oxic and an anoxic bottom layer. In the oxic layer organic matter is mineralized, thus producing ammonium. Nitrification (oxidation of ammonium) proceeds at a rate proportional to this aerobic degradation and is also restricted to the oxic layer. The anoxic layer is the site of denitrification (reduction of nitrate) which is defined as a first-rate process with respect to nitrate concentration.

\section{Calibration}

Calibration of the model proceeded by fitting model output to observed data of nitrate + nitrite, ammonium, oxygen, Kjeldahl nitrogen, Biochemical oxygen demand and total organic carbon. The calibration process consists of varying the parameter values, within predefined ranges obtained from the literature, until a good fit of model versus observed data is found.

An initial set of 'good' parameter ranges was obtained using the automatic calibration procedure of SENECA (de Hoop et al., 1993). Within these ranges additional fine-tuning was performed by man- ually adjusting the parameter values, until a fit was found that was satisfying for all variables.

Parameter values were calibrated for the period 1984-1985. For verification, the model was subsequently run for the period 1980 till 1985 (Figs 2-4), where the years 1980-1983 constitute the verification data base. In order to assess conservative behavior of the constituents, a separate model was run allowing only advective-dispersive transport and waste import (but no sedimentation). Comparing the 'conservative' mixing of the nutrients with observed data then indicates whether a variable is consumed or produced in the estuary.

For a list of best parameter values we refer to Table 5.

\section{Results}

\section{Calibration results}

\section{Ammonium (Fig. 2-left)}

Observed data and model output for MOSES spatial compartments 1 and 2 were very erratic. As these compartments are almost not influenced by tidal mixing their concentration is mainly determined by the ammonium load at the freshwater boundary. From spatial compartment 3 on a consistent seasonal cycle was apparent. Both the spatial and temporal gradients of ammonium were well represented in the model. The conservative mixing plot (compartment 8 ) shows ammonium to be consumed in the estuary.

\section{Nitrate (Fig. 2-right)}

There were not many observed data for nitrate from the three most upstream compartments, but those that were available were reasonably fitted. Nitrate in the most seaward compartments appeared to be slightly overestimated in the fall, underestimated in spring. The behavior of 'conservative' nitrate shows that nitrate is produced in the estuary.

\section{Oxygen (Fig. 3-left)}

Observed data of oxygen showed a large variability up to compartment 6 . More downstream a clear seasonal cycle was apparent. Oxygen was somewhat overestimated in spatial compartments 1 to 3 . The mean concentration was well represented from compartments 4 to 7 although model output was much less variable. Downstream from compartment 8 , the oxygen concen- 

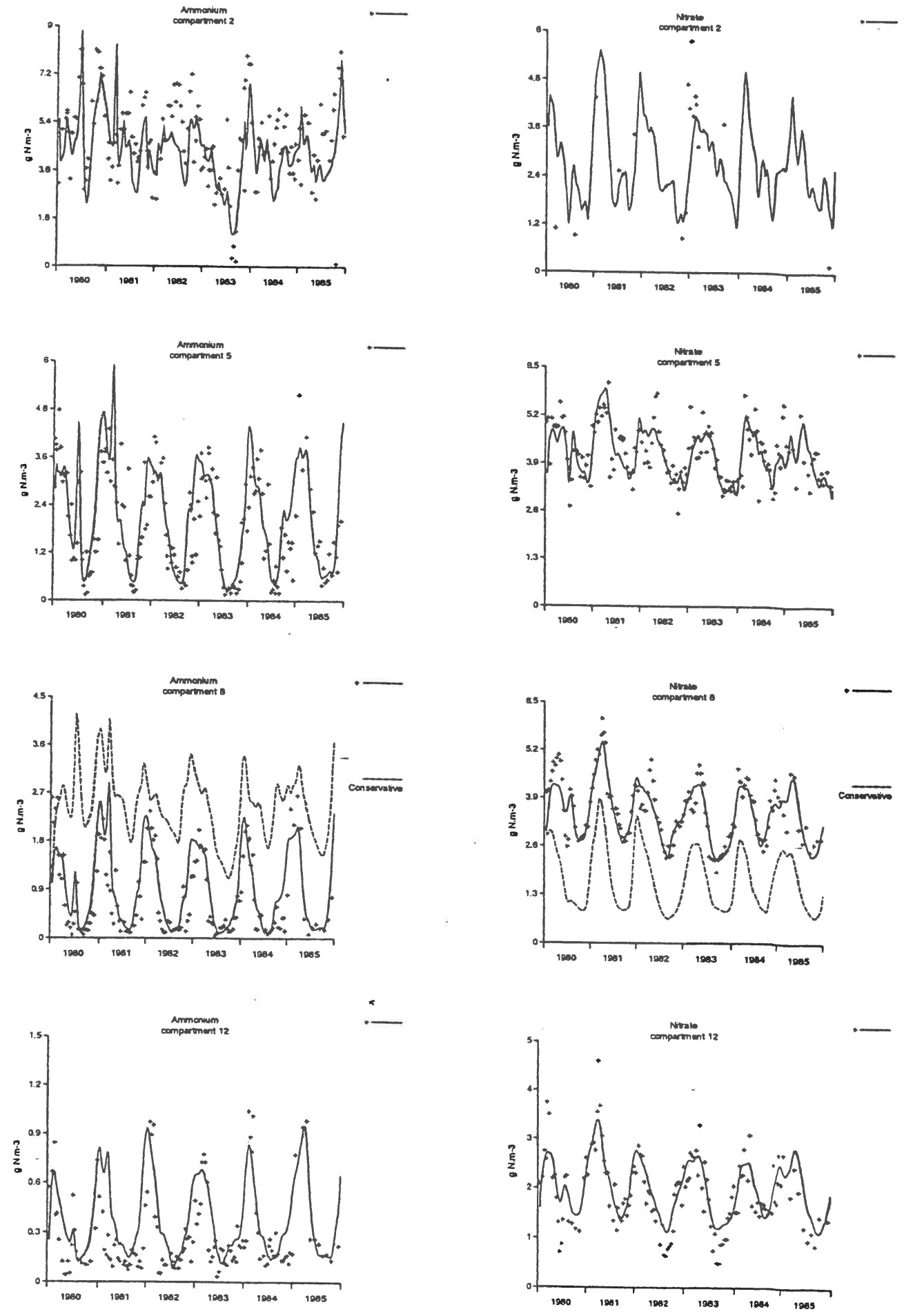

Fig. 2. Observed data ( + ) and model output of ammonium (left) and nitrate (right) for MOSES spatial pelagic compartments 2, 5, 8 and 12 The conservative concentration (only transport and waste input) of the nutrients is represented for model compartment 8 . Calibration occurred on data of 1984-1985. 

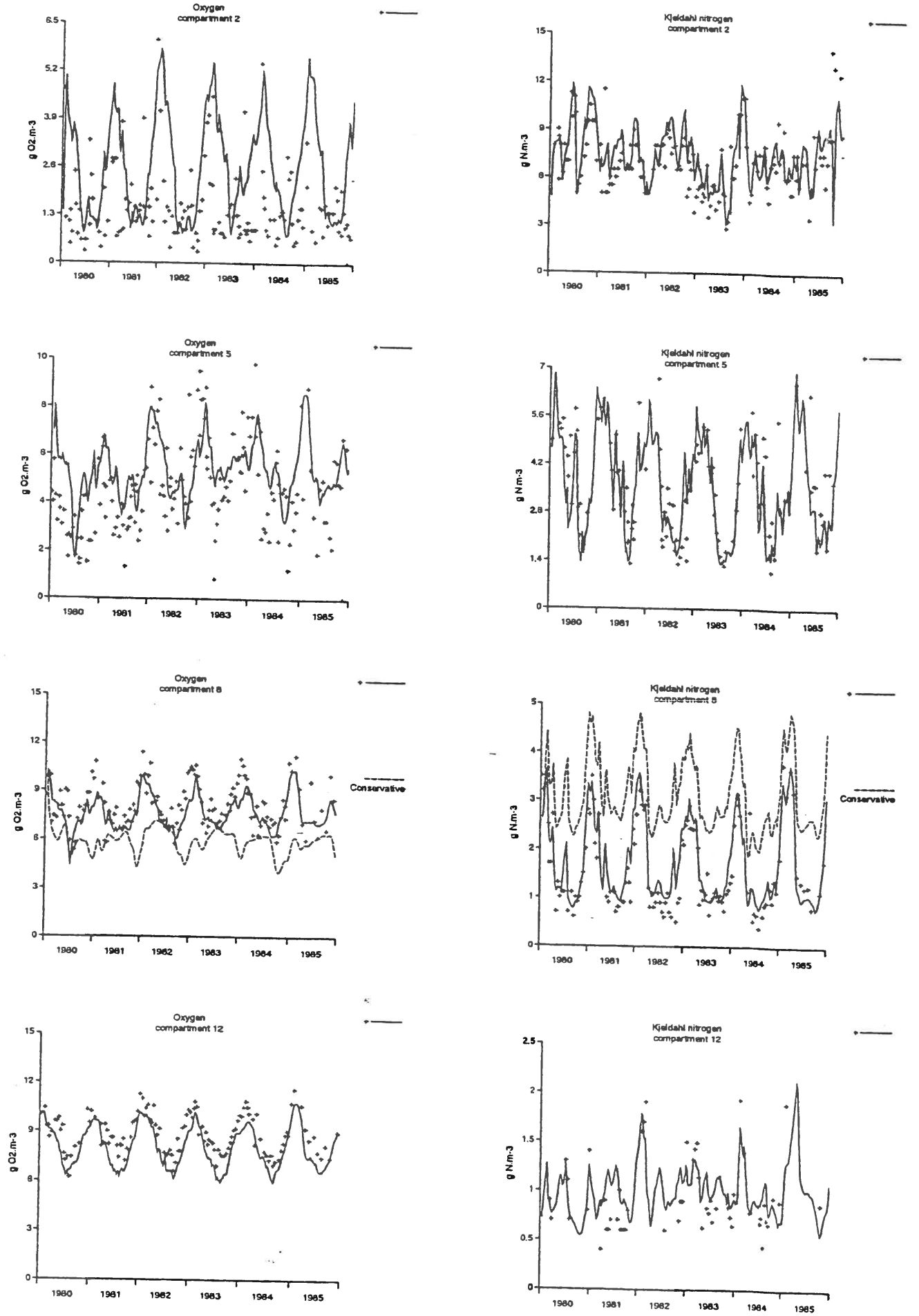

Fig. 3. Observed data (+) and model output of oxygen (left) and Kjeldahl nitrogen (right) for MOSES pelagic compartments 2, 5, 8 and 12 The conservative concentration (only transport and waste input) of the nutrients is represented for model compartment 8 . Calibration occurred
on data of 1984-1985. 

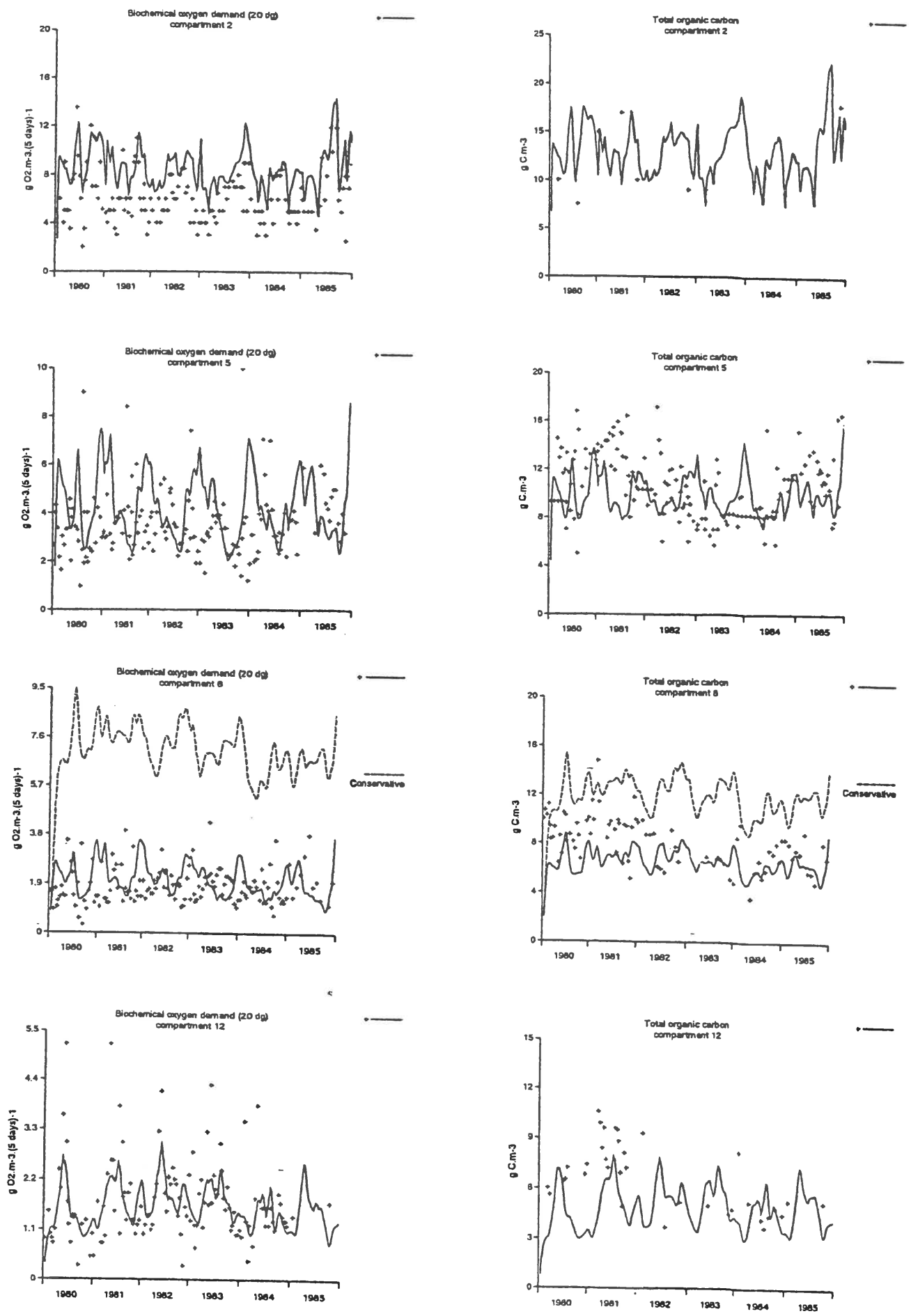

Fig. 4. Observed data (+) and model output of Biochemical oxygen demand (left) and total organic carbon (right) for MOSES pelagic compartment 8 . Calibration occurred onservative concentration (only transport and waste input) of the nutrients is represented for model 
tration was slightly underestimated but the seasonality was well represented. The conservative mixing plot shows the extent to which oxygen is added to the estuarine waters.

\section{Kjeldahl nitrogen (Fig. 3-right)}

Kjeldahl nitrogen is the sum of ammonium and total organic nitrogen. In the Westerschelde it consists for more than half of ammonium. Both the temporal and spatial pattern is well represented by the model. Comparison with conservative Kjeldahl-N shows the consuming nature of the estuary with respect to this constituent.

\section{Biochemical oxygen demand (Fig. 4-left)}

BOD values were calculated by adding all fast decaying and slow decaying pelagic components (detritus, phyto- and zooplankton) in the model and calculating the amount of oxygen necessary for the oxidation of this load during 5 days at 20 degrees. The observed data were very variable and unpredictable, whereas model output showed a seasonal trend. However, modeled values fell well within observed ranges. The conservative mixing plot reveals that biochemical oxygen demand decreases substantially in the estuary.

\section{Total organic carbon (Fig. 4-right)}

As for BOD, total organic carbon observed data showed much variability which was less pronounced in model output. There was a decrease in TOC from 1980 towards 1986 which was not reproduced by the model. The estuary acts as a consumer of TOC.

\section{Spatial and temporal patterns of organic matter and nutrients in the model (Fig. 5)}

As the model adequately fits temporal and spatial patterns of the various nutrient concentrations and organic nitrogen, we used model output to describe general trends in standing stock. A synthetic year was created by averaging over six years (1980-1985) and an additional distance weighted least squares smoothing (Systat, 1992) was performed. By doing so, much of the short-term variability in the model output has been removed such as to reveal the inherent largescale spatial and temporal signature. Moreover, these plots directly result from the calculated rates which facilitates their interpretation.

Nitrate concentrations generally increase from about $2 \mathrm{gN} \mathrm{m}^{-3}$ at the riverside to about $5 \mathrm{~g} \mathrm{~N} \mathrm{~m}^{-3}$ in the middle of the estuary, after which they steadily decline towards the sea. Nitrate concentrations peak in spring and are lowest in late summer. An additional small peak in summer is the result of higher nitrification rates in the estuary then. Ammonium concentrations fall drastically from about $6 \mathrm{gN} \mathrm{m}^{-3}$ near the river to low levels at the sea side. In summer, ammonium concentrations are minimal, highest concentrations are attained in winter. Oxygen concentrations steadily increase towards the sea and from summer to winter. A small increase in oxygen concentration, due to primary production, is visible in mid-summer.

Organic nitrogen peaks in the model in the maximum turbidity zone (model compartment 2 ) in winter and fall. In summer, a smaller maximum is present more upstream (mainly freshwater algae). Organic nitrogen generally decreases from the freshwater boundary towards the sea, except in summer when concentrations are rising slightly from the midestuary downstream.

\section{Spatial and temporal patterns of the various processes in the model (Fig. 6)}

Aerobic mineralisation is nearly entirely patterned to the organic nitrogen load, but is more pronounced in summer (temperature effect). Also the increase of mineralisation rates towards the sea is more pronounced than for organic nitrogen content. This reflects the reactivity of the organic matter which is higher near the sea due to import of relatively labile marine organics.

Denitrification rate in the water column is highest in the badly aerated water masses. It peaks in summer and is highest in spatial compartment 2 , which has the best mix of (high) nitrate and (low) oxygen concentration. A smaller amount of nitrogen is lost due to denitrification in the bottom. Sediment denitrification is most pronounced in pelagic spatial compartment 7 which has the most extensive tidal flats.

Nitrification in the water column is highest in summer and in the most upstream compartment, where ammonium concentration is highest. The amount of nitrogen incorporated into bacterial biomass by this process is small.

Nitrogen uptake of the phytoplankton is function of the net primary production, which in turn is determined by light intensity, turbidity and standing stock. In summer net production in the model is positive and nitrogen is taken up by algal cells. There is a sharp decline of net productivity towards the maximum turbidity zone (spatial compartment 2) after which $\mathrm{N}$ uptake by phy- 
Nitrate + nitrite

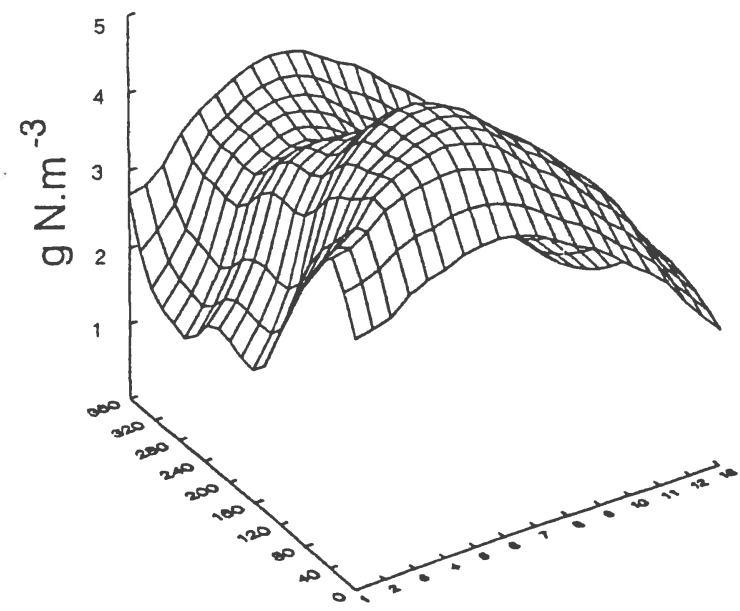

Organic nitrogen

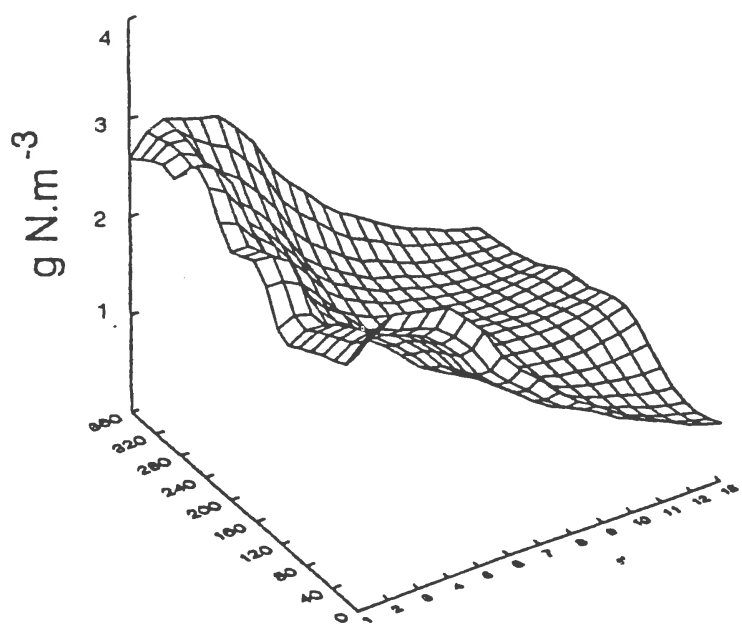

Ammonium

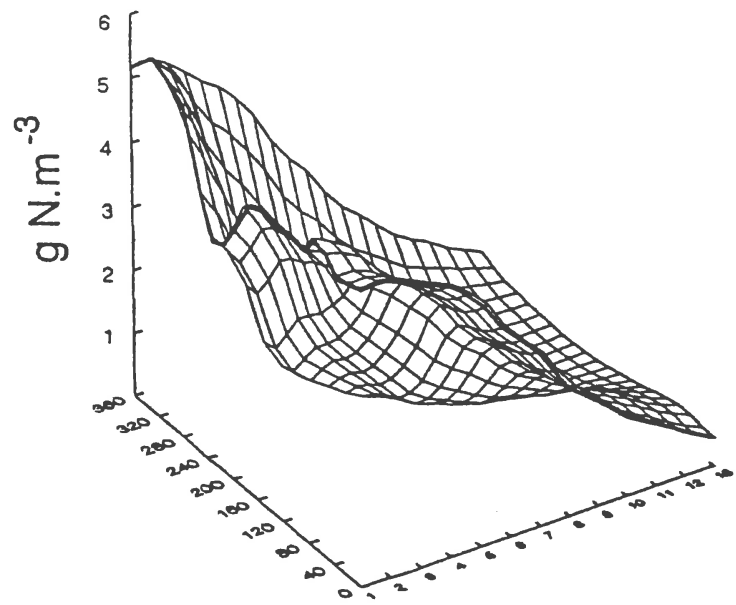

Oxygen

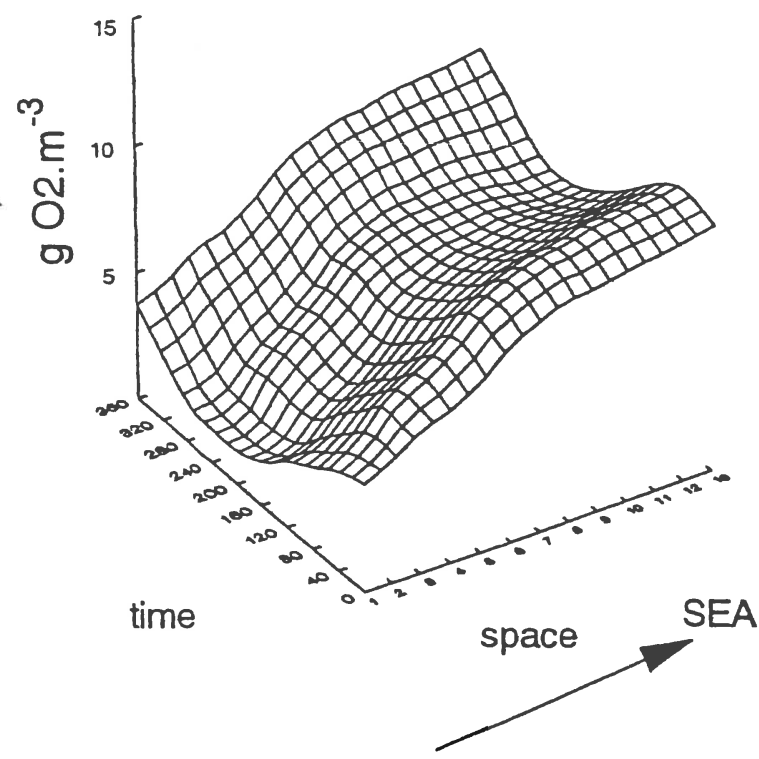

Fig. 5. Temporal and spatial patterns of the various nitrogen species and oxygen. (six-years average of model output). The $\mathrm{X}$ axis represents the number of the pelagic model compartment. The $Y$ axis gives the day number (starting at 1 jan).

toplankton gradually increases towards the sea. The slight dip in compartment 9 is due to the unfavourable proportion of shallow and deep regions in this compartment. In winter, light intensity on the surface is lower and turbidity in the estuary is higher. As a result phytoplankton respiration exceeds gross primary pro- duction in the model which implies a net production of inorganic nitrogen. For more information about the implementation and description of phytoplankton production we refer to Soetaert et al. (1994). 


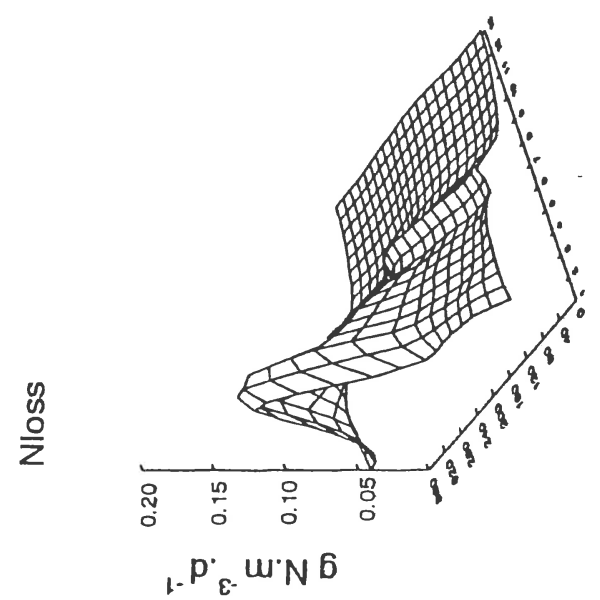

$\frac{1}{0}$
$\frac{1}{c}$
$\frac{10}{0}$
$\frac{0}{0}$
$\frac{1}{c}$
$\frac{1}{0}$
$\frac{0}{10}$
$\frac{0}{0}$
$z$
$z$
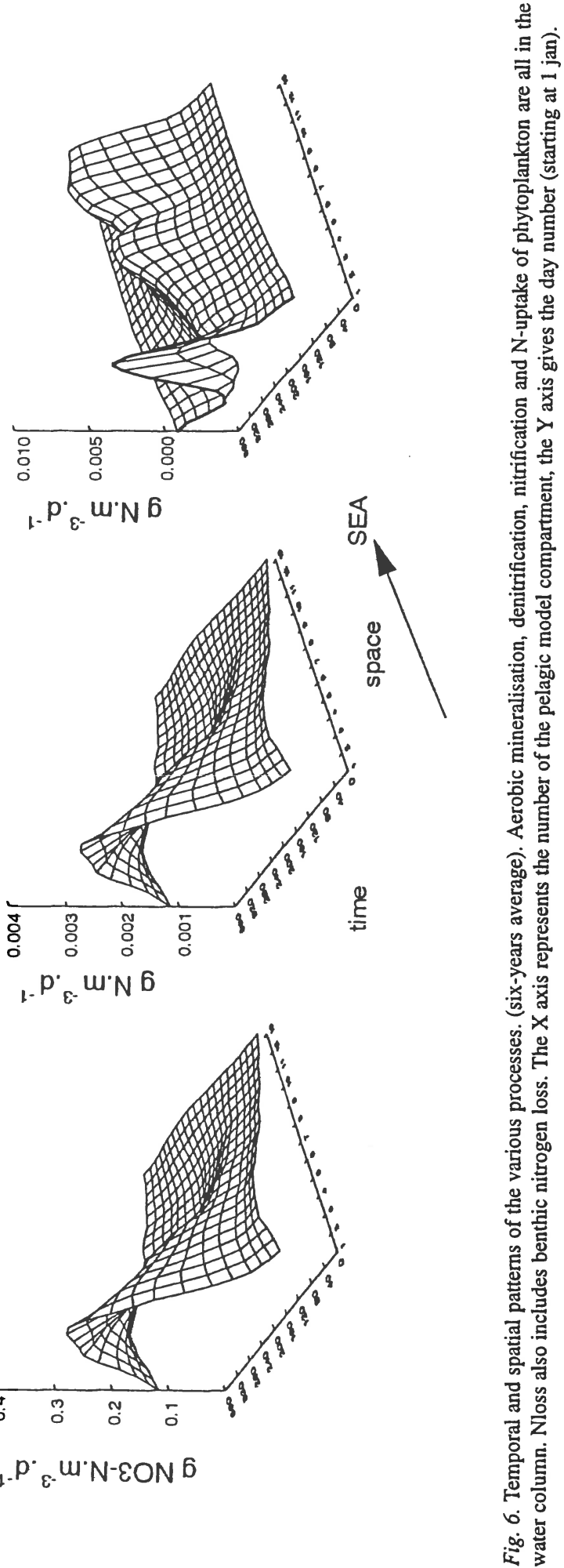

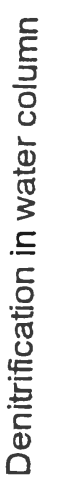
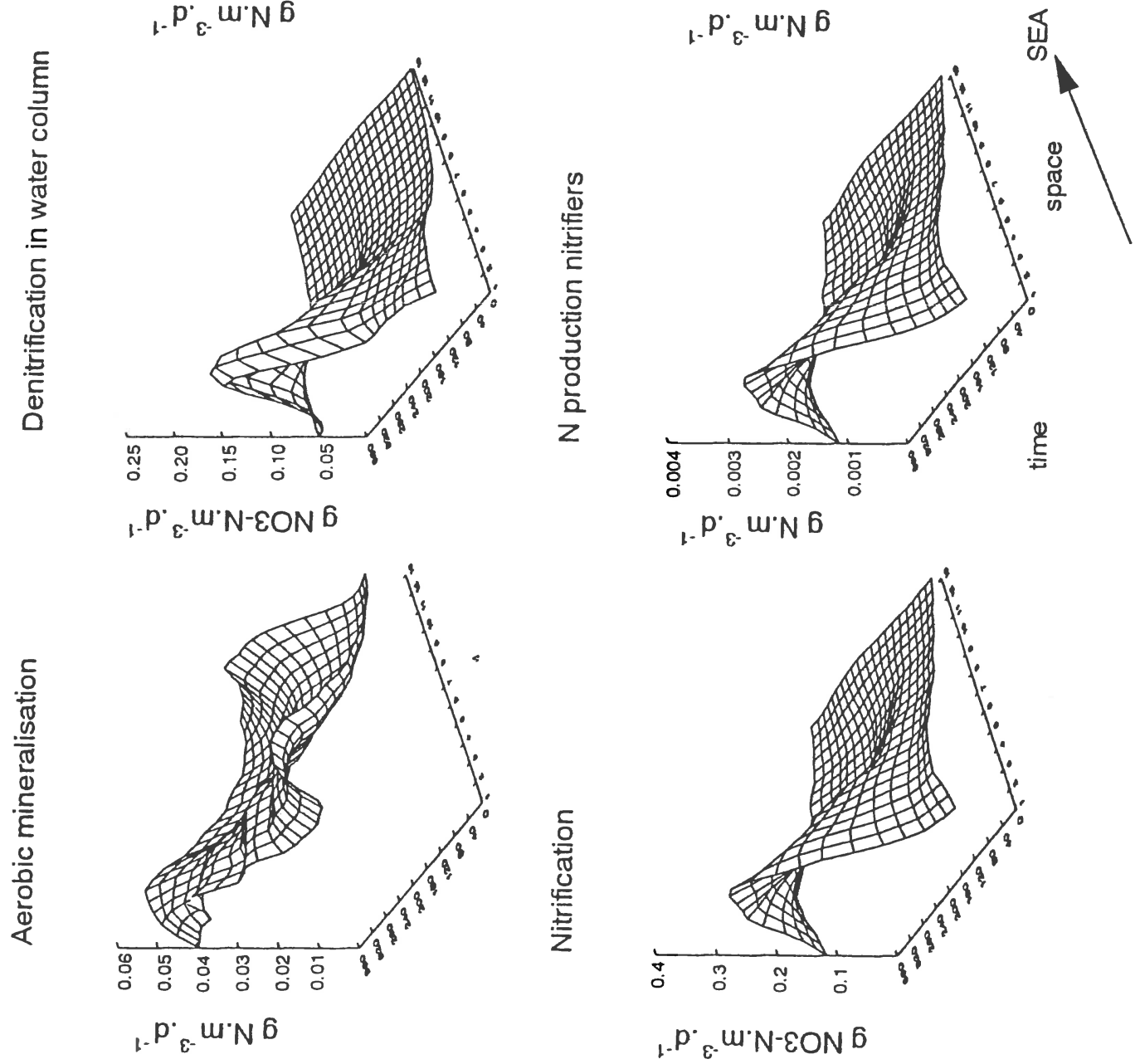

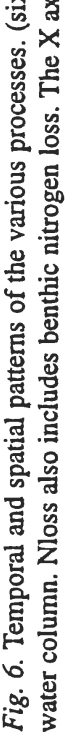




\section{A yearly averaged nitrogen budget (Figs 7-9)}

The estuary is mainly funnel shaped and the cross sectional surfaces at the freshwater and the marine boundary are in the proportion of 1 to 20 . Thus certain processes, although occurring at much higher rates in the most upstream part of the estuary could prove to be unimportant at the scale of the entire estuary.

Yearly averaged rates are represented in Fig. 7. This figure indicates the importance of each process with respect to nitrogen concentration in a certain spatial compartment. The total amount of nitrogen that is transformed in a transverse cross-section of $1 \mathrm{~m}$ length is represented in Fig. 8. It reflects the impact of the process at a certain point along the estuary with respect to total nitrogen load.

Except for phytoplankton uptake, the rates of pelagic processes decrease towards the sea (Fig. 7). Benthic rates (expressed per pelagic units) are most pronounced in spatial compartment 7 , which has the most extensive tidal flats (Fig. 7). With the exception of (pelagic and benthic) denitrification, the impact of all processes on total nitrogen load increases towards the sea (Fig. 8).

Nitrification has the greatest impact on the nitro-

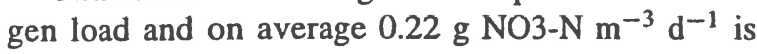
produced in the most upstream compartment (Fig. 7). Regeneration of ammonium by means of aerobic mineralisation proceeds at a much lower rate than its consumption by the nitrification process. Denitrification is the second most important process in the brackish part of the estuary. It is mainly located in the water column. In the most aerated water masses downstream, pelagic denitrification rates are very small (less than $0.01 \mathrm{~g}$ NO3-N m$~^{-3} \mathrm{~d}^{-1}$ ) (Fig. 7). But here too more than 60 percent of total nitrogen loss is occurring in the water column due the unfavourable volume/surface ratio in these compartments (Fig. 8). Only in MOSES spatial compartment 7 , with its extensive tidal flats, more than $50 \%$ of total nitrogen loss occurs in the bottom. Phytoplankton uptake is unimportant in the Westerschelde nitrogen budget. On a yearly basis, net nitrogen production by algae (due to mortality and lysis of imported algal cells) is higher than total algal nitrogen uptake in MOSES spatial compartments 2, 3 and 4. The phytoplankton in the other compartments is a net consumer of ammonium.

A yearly integrated budget (average of the years $1980-1985$ ) is given in Fig. 9. Only about $30 \%$ of total ammonium entering the estuary leaves at the mouth. Nitrate discharge into the sea is about three times high- er than what comes in. Organic nitrogen enters the estuary as part of the river load, in waste discharges and from the sea. 26000 tonnes of organic nitrogen is lost within the estuary per year, mainly by means of (aerobic and anoxic) pelagic degradation. The remainder sediments to the bottom.

Of the 71000 tonnes of nitrogen that enters the estuary per year, only 56000 tonnes are exported to the sea. Thus about $21 \%$ of total nitrogen import is lost in the estuary per year.

\section{Discussion}

The Westerschelde estuary is a passage of waters from the river Schelde watershed to the southern Bight of the North Sea. Tidal currents result in the mixing of fresh and sea water and the Westerschelde nutrient composition to some degree reflects both endmember concentrations. Superimposed on these hydrodynamical forces are the various biological and chemical processes that react in concert and further change the nutrient load.

Whereas concentrations of nutrients in the watercolumn are relatively easy to measure, their interpretation is more difficult. Frequently the concentration is plotted against a conservative index of mixing (chlorinity) and the resulting mixing plots are interpreted as indicative of removal, addition or conservative behavior of the nutrient. However, seasonal variations in the freshwater and marine nutrient concentrations and chlorinity may complicate the interpretation as they result in 'pulses' of nutrients that propagate through the estuary in time (Loder \& Reichard, 1981).

A mathematical model is an ideal tool to evaluate the different processes that change the nutrient composition in estuaries. Being based on a well-calibrated transport model (Soetaert \& Herman, 1995a), the effect of the ever changing nutrient concentration at the boundaries is now included into the model and this should make the influence of biochemical and biological processes more obvious.

The Westerschelde estuary is especially interesting due to the high load of detritus and nutrients. This, combined with the relatively high residence times in the estuary (50 to 70 days in Soetaert \& Herman, 1995a) results in clear and temporally consistent patterns of the various nutrients (Nixon \& Pilson, 1983), which makes the Westerschelde an ideal area for modelling. 


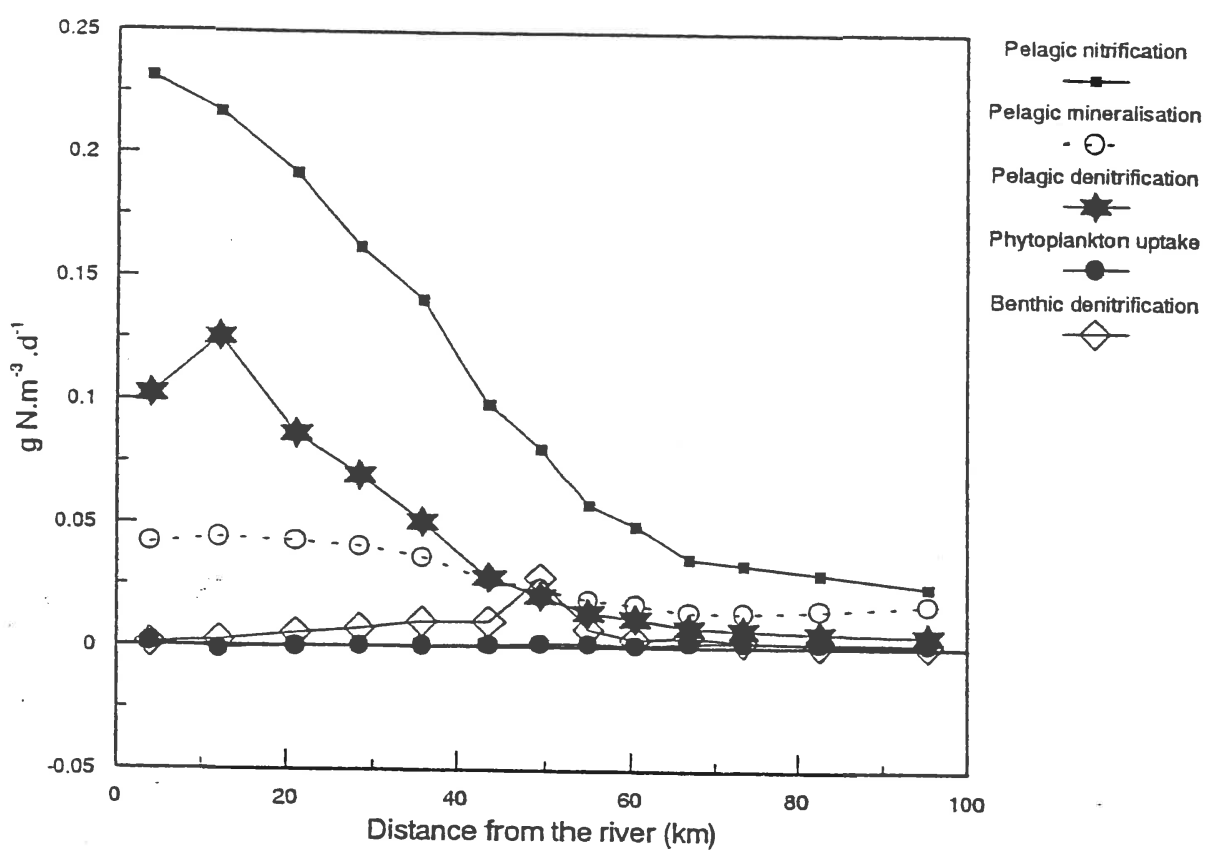
Fig. 7. Yearly averaged process rates $\left(\mathrm{g} \mathrm{N} \mathrm{m}^{-3} \mathrm{~d}^{-1}\right)$ for the different compartments. Pelagic nitrification and pelagic denitrification is in $\mathrm{g}$
$\mathrm{NO}_{3}-\mathrm{N} \mathrm{d}^{-1}$, benthic denitrification is in $\mathrm{g} \mathrm{N} \mathrm{d}^{-1}$ lost to the atmosphere.

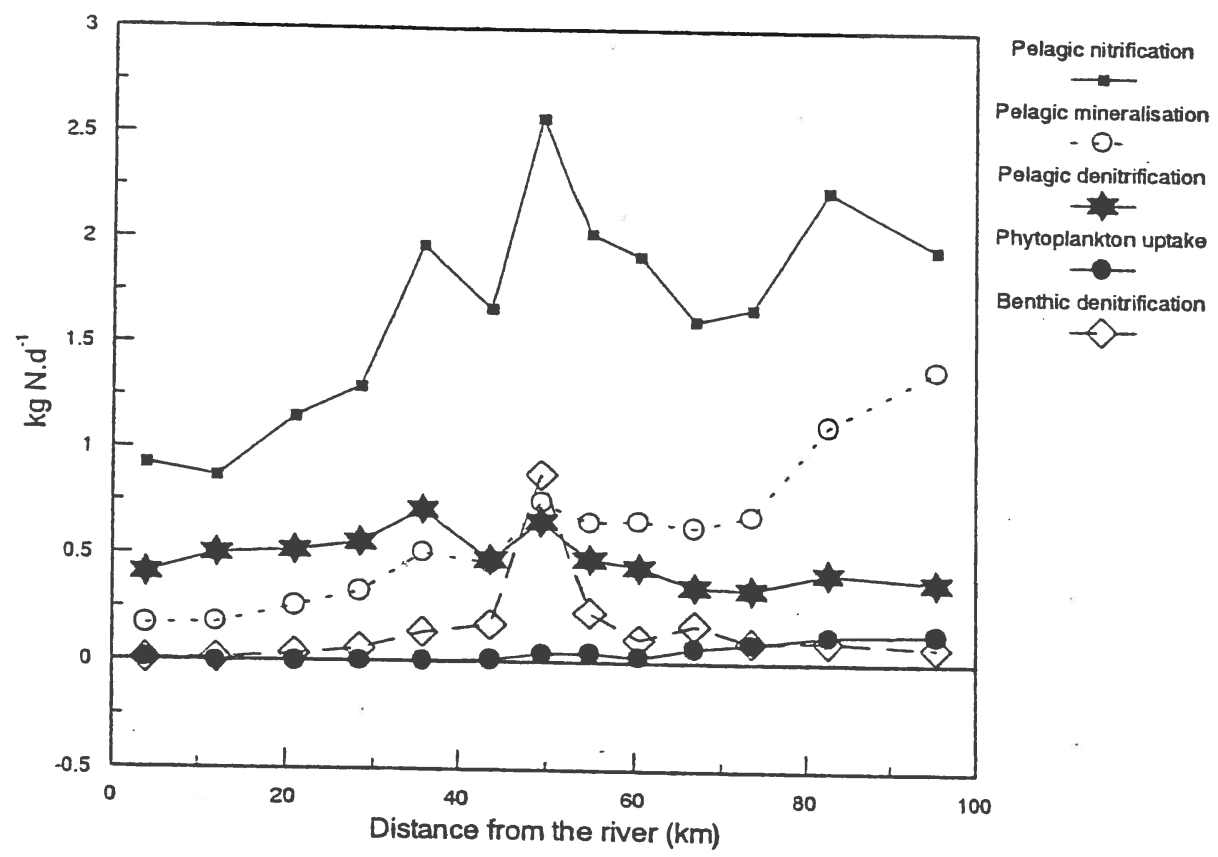

Fig. 8. Yearly averaged nitrogen budget (in $\mathrm{kg} \mathrm{N} \mathrm{d}^{-1}$ ) for a transverse cross-section of $1 \mathrm{~m}$ length. Pelagic denitrification and pelagic denitrification is in $\mathrm{kg} \mathrm{NO}_{3}-\mathrm{N} \mathrm{d}^{-1}$, benthic denitrification is in $\mathrm{kg} \mathrm{N} \mathrm{d}^{-1}$ lost to the atmosphere.

The major sources of nitrogen to the estuary are the river and waste discharges (Wattel \& Schouwenaar, 1991). The majority of this supply (about 70\%) is as inorganic nitrogen, the remainder consists of detritus.

Among the various biochemical processes that act on this nitrogen load, nitrification has the largest effect 


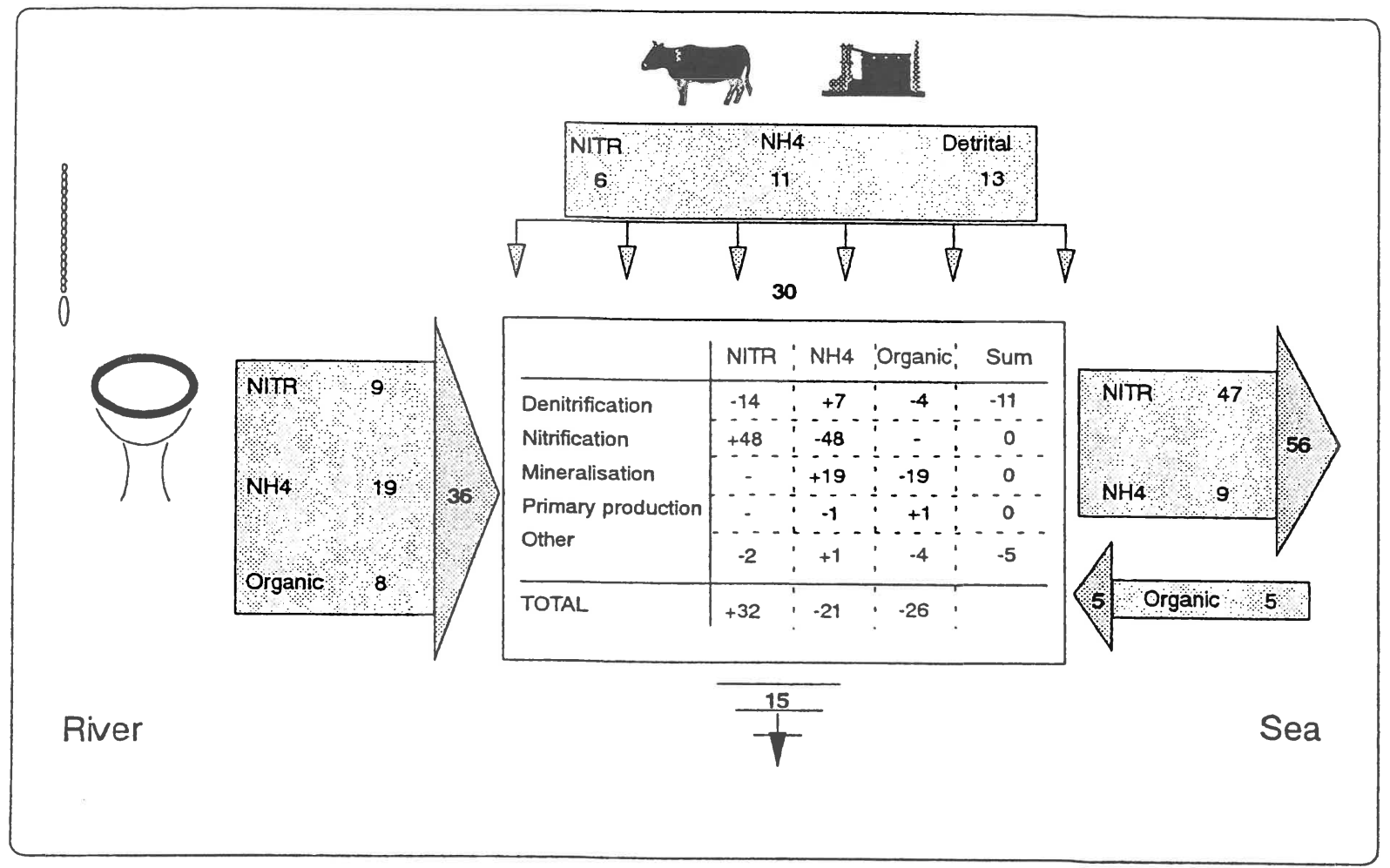

Fig. 9. Global nitrogen budget in the Westerschelde in 1000 tonnes $\mathrm{N} \mathrm{yr}^{-1}$. Denitrification, nitrification, aerobic mineralisation and primary production are all in the water column. 'Other' = gain/loss to the bottom or due to excretion processes of the higher trophic levels (NH4) Positive values = gain, negative = loss. The arrows to the left indicate import from the river, to the right are exchanges with the sea. The small arrows on top indicate waste discharges.

on the speciation. The process occurs whenever aerobic conditions are restored in the estuary (Wollast, 1983). In the Westerschelde model, the zone of highest nitrification is in the upper estuarine part and ammonium is almost completely consumed by this process, especially in summer when nitrification rates are most pronounced. Thus the nitrate concentration increases up to about the Belgian-Dutch border. From then on nitrate concentration gradually decreases due to dilution with sea-water. On average about 47000 tonnes of nitrate- $\mathrm{N}$ are discharged per year into the sea whereas only 15000 tonnes are imported into the estuary. In contrast to nitrate, the estuary acts as a consumer of ammonium such that only $30 \%$ of the total input is discharged into the sea. This net consumption of ammonium is due to the fact that aerobic mineralisation and other ammonium generating processes are not able to meet the losses due to nitrification.

More important in terms of the global nitrogen budget is the process of denitrification. This is the heterotrophic reduction of nitrate to $\mathrm{N}_{2}$ or $\mathrm{N}_{2} \mathrm{O}$ which are lost to the atmosphere (Seitzinger, 1988). The nor- mal site of denitrification is in the bottom, but in the Westerschelde the process can also occur in the water column when oxygen conditions are bad (Billen et al., 1985). In our model, denitrification is negatively influenced by higher oxygen conditions but continues up to the sea in the water column, albeit at very low levels. Due to the high load of organic matter in the water column, small-scale gradients of oxygen will be created in detrital particles of a certain size. Because of the dependence of denitrification both on oxic conditions (which provide nitrate) and anoxic conditions (to reduce nitrate), these microscale gradients could be ideal sites for denitrification (Law \& Owens, 1990). Thus we assumed that the process can take place at a very short distance to the nitrification in an otherwise oxygenated water column. The same implementation strategy was adopted in the model of lake Grevelingen (Vries et al., 1988). Evidence that nitrifiers can under anaerobic conditions reduce nitrate to $\mathrm{N}_{2} \mathrm{O}$ (Kaplan, 1983; Goreau et al., 1980) further justifies this implementation strategy. Denitrification rates are highest in MOSES compartment 2, which has the best mix of 

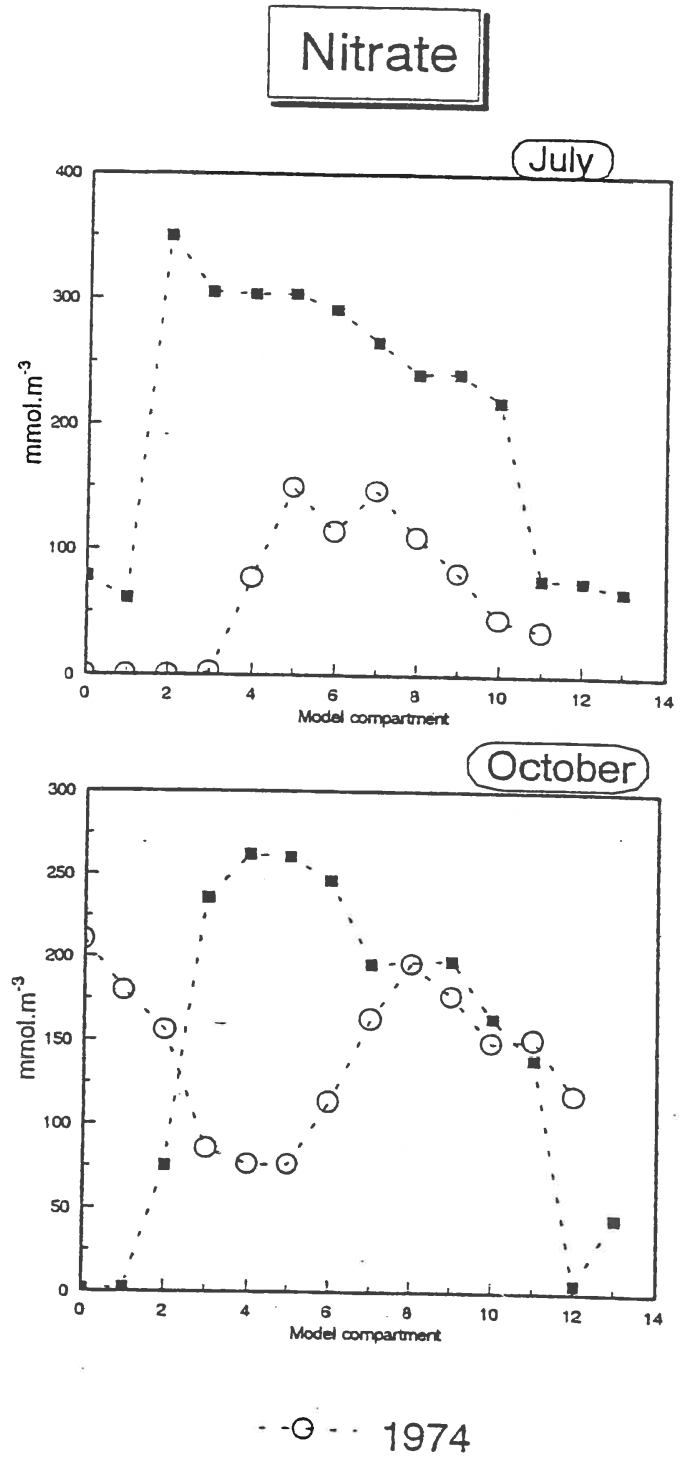

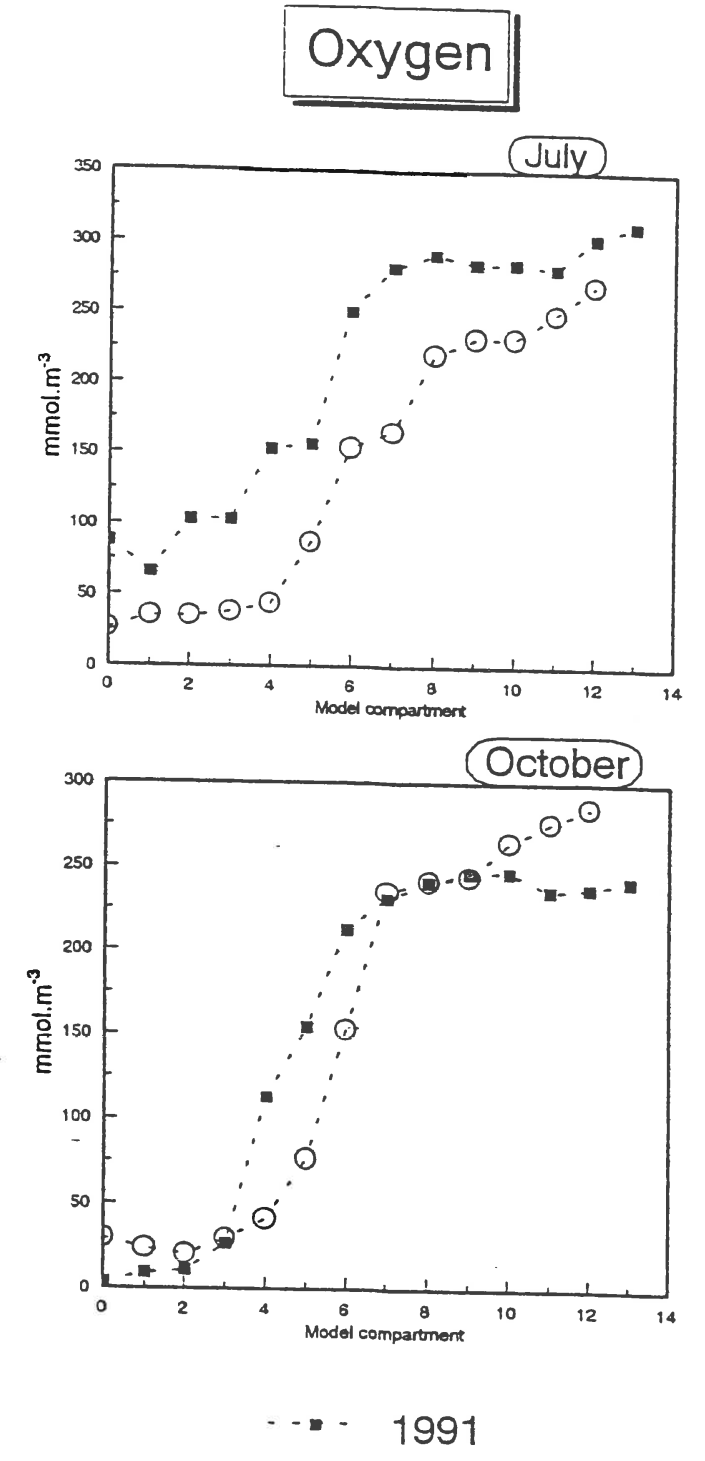

Fig. 10. Comparison of a typical nitrate and oxygen profile in summer and fall 1974 (Billen \& Smitz, 1976) and 1991 (data from the JEEP data base). Data from 1974 were transposed to mid-tidal level.

nitrate load and anoxia. This is somewhat more downstream than the peak of nitrification. In the Westerschelde, it has been shown that a clear $\mathrm{N}_{2} \mathrm{O}$ peak occurs upstream from the nitrate peak (Deck, 1980 in Nixon \& Pilson, 1983), but somewhat downstream from the offset of nitrate production. This is consistent with the position of the denitrification peak in our model.

Part of the denitrification occurs on the intertidal and subtidal flats. The magnitude of this nitrogen loss was determined by means of a diagenetic model proposed by Lancelot \& Billen (1985). Thus in the model yearly-averaged denitrification rates of 0.07 to $0.3 \mathrm{gN} \mathrm{m}^{-2} \mathrm{~d}^{-1}$ were calculated in the intertidal area. This range is comparable to denitrification rates of 77 to $1067 \mu \mathrm{mol} \mathrm{N} \mathrm{m}{ }^{-2} \mathrm{hr}^{-1}\left(0.03-0.36 \mathrm{gN} \mathrm{m}^{-2}\right.$ $\mathrm{d}^{-1}$ ) reported from estuarine sediments in Seitzinger (1988). 

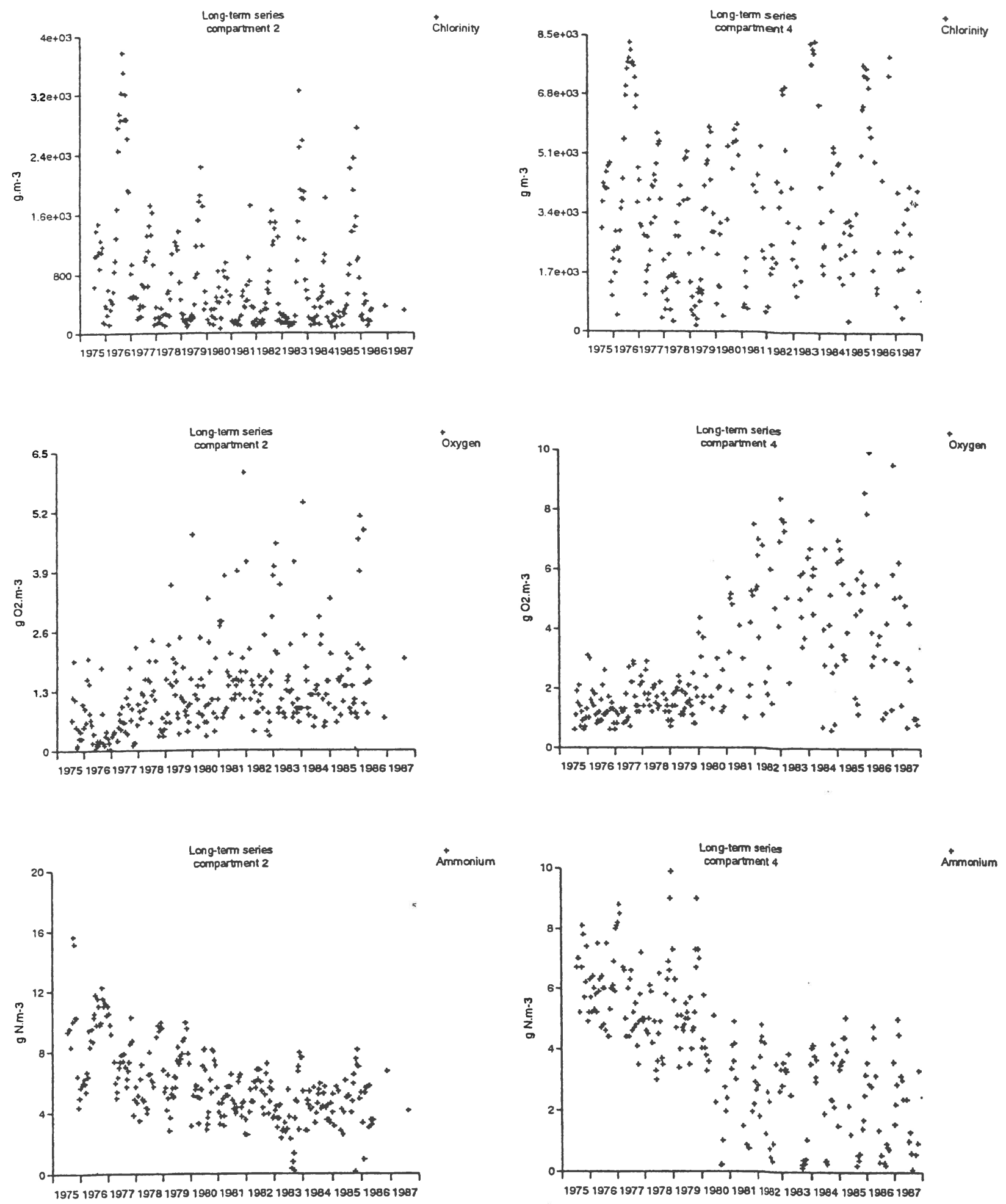

Fig. 11. See p. 243 for legend. 


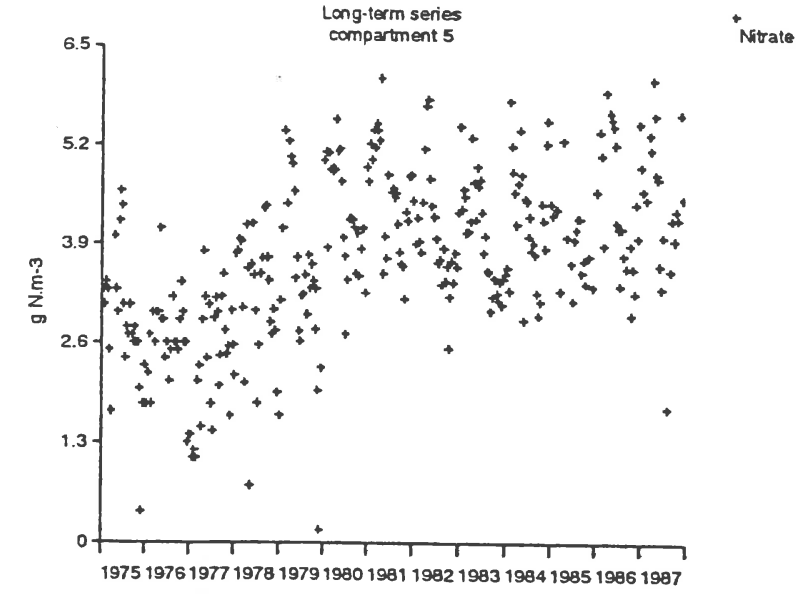

Fig. 11. Long-term series of chlorinity, oxygen, ammonium and nitrate in pelagic spatial compartment 2 and 4 ( 5 for nitrate).

In the model, the largest amount of nitrogen is lost by pelagic rather than by benthic denitrification. A small calculation shows the extent of benthic denitrification if all nitrogen loss $\left(15000\right.$ ton $\left.\mathrm{N} \mathrm{yr}^{-1}\right)$ would be in the Westerschelde bottom. Assuming denitrification occurs equiproportional on the entire Westerschelde bottom $\left(260 \mathrm{~km}^{2}\right)$ then yearly averaged denitrification rates would be $15000 / 260 / 365=0.16 \mathrm{gN} \mathrm{m}^{-2} \mathrm{~d}^{-1}$. In reality, the main sedimentation occurs on the intertidal flats $\left(59 \mathrm{~km}^{2}\right)$. Overall intertidal nitrogen loss would necessitate a yearly averaged denitrification rate of $0.7 \mathrm{gN} \mathrm{m}^{-2} \mathrm{~d}^{-1}$. Both estimates are close to or larger than the maximal denitrification rates, reported in Seitzinger (1988) of $0.36 \mathrm{gN} \mathrm{m}^{-2} \mathrm{~d}^{-1}$ for an area in the Tagus that receives a large amount of sewage. The amount of carbon sedimenting on the Westerschelde bottom was estimated to be $2110^{3}$ tonnes of carbon per year (Soetaert et al., 1995b), half of which occurs in the downstream part of the estuary. In order to meet the demands of whole-benthic nitrogen loss, it would be necessary that more than $70 \%$ of all benthic degradation would occur by means of denitrification (or 60\% if phytobenthic production were to be included).

Jørgensen \& Sørensen (1985) showed that denitrification was an insignificant pathway of organic caron oxidation in the sediment of a Danish estuary (3$4 \%$ ). The main processes were oxygen uptake and sulfate reduction, while nitrate reduction to ammonium was important in the brackish part. More significance of benthic denitrification was suggested by Seitzinger (1988), who reported that the process in marine and estuarine sediments accounted for $20-70 \%$ of total sediment-water nitrogen fluxes in estuaries.
Whether benthic or pelagic, all included, a load of about 40 tonnes of nitrogen is lost to the atmosphere per day, which amounts to about 15000 tonnes per year, i.e. $21 \%$ of total nitrogen import, $33 \%$ of inorganic nitrogen input. This value is rather low as other estuaries that were examined thus far had a surprisingly narrow range of 40 to $50 \%$ removal of inorganic nitrogen input (Seitzinger, 1988). In the Danish estuary examined by Jørgensen \& Sørensen (1985) on the other hand, (benthic) denitrification removed only $5 \%$ of total nitrate import.

Due to high turbidity in the water column, depth-integrated net phytoplankton production is low (Soetaert et al., 1994) and the nutrient loss due to this process is insignificant in the global estuarine cycle.

A major uncertainty in many budget approaches is a lack of detailed knowledge on the role of organic nitrogen, although it is considered to be a substantial part of the budget (Meybeck, 1982). The pathway of organic matter through the estuary strongly depends on its partitioning over dissolved and particulate forms. The incorporation of particulate matter into a mathematical model is more complicated than for dissolved substances as they exhibit an aberrant transport behavior which is hard to describe in one, or even two dimensions (Odd, 1988).

In the Westerschelde, sediment particles from both the river and the sea enter the estuary and are accumulated in the zone of maximum turbidity (Van Eck \& de Rooij, 1990). As these transport and accumulation processes were deemed to be important for the particulate organic matter, we implemented a simple model that represents the horizontal and vertical movement of particulates in the Westerschelde (Soetaert \& Herman, 1993). Although crudely modeled, the general gradients (turbidity maximum) and seasonality of suspended matter were adequately represented. Also, the net import of sediment from both the river and the sea (yearly values) and total sedimentation of mud and organic carbon were convincingly represented (see Soetaert \& Herman, 1993 for more details).

In the model, the Westerschelde consumes particulate nitrogen both from freshwater, waste and marine origin and about 26000 tonnes of organic nitrogen is trapped or lost in the estuary per year. As the estuary acts as a net exporter of organic carbon to the sea (Wollast, 1976; Soetaert \& Herman, 1995b), the fact that in the model marine organic nitrogen is net imported into the estuary deserves some attention. This imbalance is created as fast decaying detritus (with high nitrogen content) enters the estuary, while more refractory (and 
nitrogen-poor) detritus net leaves the estuary. However, virtually nothing is known about the degradability and nitrogen content of marine versus estuarine organic matter which makes the direction of both fluxes difficult to estimate based on observations. The exchange in the model could be an artefact due to the fact that a fixed (and maybe too large?) amount of total marine detritus was assumed to be fast decaying. Nevertheless, there is evidence of at least one pool of (nitrogen-rich) carbon that is net imported from the sea into the estuary: each year about 1500 tonnes of marine zooplankton dry weight drifts into the estuary where it decays (Soetaert \& Herman, 1994). Several other estuarine environments appear to represent both efficient traps for river-borne particulate organic carbon (Fontugne \& Jouanneay, 1987; Lucotte et al., 1991) and sinks for a significant fraction of the carbon metabolized in the coastal area (Tan \& Strain, 1978; Gearing et al., 1984).

The oxygen concentration proved to be the most difficult to fit by means of our model. We had to find a trade-off between too high concentrations near the fresh-water boundary and too low concentrations near the sea side. The reason for this discrepancy as yet is unclear, but there is a possibility of an oxygendemanding process in the upstream part that is unaccounted for in the model, while atmospheric reaeration could be higher than included in the model. In the most upstream compartments, a substantial amount of dredging takes place. The main process of organic matter degradation in the sediments of the brackish and marine part could be by means of sulfate reduction (Middelburg, pers. comm.) and the release of the reduced forms of sulfur in the water column, where they would be oxidized quickly, could provide an additional oxygen demand in the upper estuarine compartments. Similarly, methane produced in the riverine part of the Schelde could oxidize quickly when oxygen conditions improve and hence retard restoration of oxygen concentrations in the water (Middelburg, pers. comm.).

Compared to a previous model of nitrogen cycling in the Westerschelde (Billen et al., 1985, 1986, 1988), we model lower maximal denitrification rates in the water column $\left(0.25 \mathrm{gN} \mathrm{m}^{-3} \mathrm{~d}^{-1}\right.$ compared to $0.7 \mathrm{gN}$ $\mathrm{m}^{-3} \mathrm{~d}^{-1}$ in Billen et al., 1985) while only about $21 \%$ of total nitrogen, $33 \%$ of inorganic nitrogen, is removed in our model compared to $40-50 \%$ as estimated by Billen and co-workers. This discrepancy requires a more thorough analysis. Part of the differences could be methodological: Billen and co-workers defined the estuarine boundaries at ebb tide, as opposed to midtide in our model. Moreover, denitrification was not dynamically simulated by Billen et al. (1985) but its magnitude was assessed by substraction of export from the total import of nitrogen. Inspection of nitrogen and oxygen profiles along the estuary nevertheless revealed a large difference between typical profiles of the seventies (after transposing them to mid-tidal level, e.g. Billen \& Smitz, 1976; Billen et al. 1985; Somville, 1980 in Wollast, 1983) with respect to the eighties and early nineties (this paper). This is represented in Fig. 10. In fall 1974, nitrate concentrations declined very rapidly from high values at the freshwater boundary towards the middle estuarine region. This decline was accompanied by a small decrease in oxygen concentration. Nitrate and oxygen levels were rising from model spatial compartment 5 towards the sea after which, due to dilution with sea water, nitrate concentration declined further downstream. In summer 1974, nitrate was entirely exhausted when entering the estuary and restoration (nitrification) did not start before spatial compartment 4 when oxygen conditions were slightly improving. Maximal nitrate concentrations in the middle estuarine part never exceeded $3 \mathrm{gN} \mathrm{m}^{-3}$ in the seventies. Profiles that were used for our model and from the nineties (data from the JEEP database, courtesy J. Kromkamp) showed another nutrient behavior. Nitrate and oxygen concentrations increased almost immediately upon entering the estuary. Moreover, nitrate concentrations in the middle estuarine part attained larger values of up to $8 \mathrm{gN} \mathrm{m}^{-3}$ in 1991. Thus it seems as if the oxygen-deficient zone has moved upstream for about 10 kilometres since the late seventies. As pelagic denitrification occurs in these badly aerated water masses, the magnitude of nitrogen loss could have diminished concurrently, which explains the lower values reported in our study. Furthermore, nitrification, which was insignificant in the upper estuary in the seventies (Billen et al., 1985) now proceeds immediately upon entering the estuary. A long-term series of oxygen, nitrate and ammonium covering the years 1975 to 1987 (Fig. 11) indeed confirms that oxygen conditions in the upstream compartments improved. Concurrently the load of ammonium has decreased, while nitrate increased almost abruptly in 1980. Chlorinity data from the same period seem to witness that this improvement could not have been caused by differences in river discharge alone, but also represent real biogeochemical changes. Interestingly, whereas the amount of nitrogen imported into the estuary from the river or waste discharges has not 
changed a great deal (52000 tonnes in Billen et al., 1985 ; 66000 tonnes in our model), the amount discharged into the sea seems to have doubled $(27000$ vs 51000 ). This is exactly what was put forward by Billen et al. (1985).

A yearly export of 51000 tonnes of nitrogen to the coastal system seems a formidable amount. It amounts to about $3 \%$ of the total nitrogen input to the North sea (1.5 $10^{6}$ tonnes $\mathrm{N} \mathrm{yr}^{-1}$ in Law \& Owens, 1990), whereas the contribution of fresh water discharge from the Westerschelde to the North sea is about ten times as low (calculated based on total fresh-water fluxes in Otto et al., 1990). Taking an average flood volume of $103010^{6} \mathrm{~m}^{3}$ (Van Maldeghem, 1988) and the nitrogen concentration in the sea water, we calculated the degree to which coastal waters are enriched with nitrogen upon mixing with the estuarine waters. Yearly averaged, the nitrogen load of coastal waters that enter and leave the estuary with the tides increased with about $14 \%$ per day. As these waters are trapped into a coastal gyre in front of the estuarine mouth (Nihoul \& Ronday, 1975), this increase in nutrient load remains apparent, especially in winter. This results in a considerable phytoplankton spring bloom which is higher than in the Channel (Brockmann et al., 1988).

In this paper we presented a set of chemical and biological processes that can explain nutrient behavior observed in the Westerschelde. As for so many modeling studies, the correctness of our results are mainly consolidated by an adequate description of the standing stock of several relevant variables. In the future a further evaluation of the proposed mass balances should be performed by means of in situ measured fluxes. Nevertheless, inherent environmental variability - especially in the benthos - will probably make it difficult to verify or falsify the estimates that are presented here.

\section{Acknowledgments}

This model was developed as part of the MAST-JEEP project of the C.E.C. and of the ECOLMOD project of Rijkswaterstaat (D.G.W.).

Thanks to Dr Van Eck and A. Schouwenaar for providing us with the data necessary for the construction of the model. This is article number 730 of the NIOO-CEMO. C. Heip, J. Middelburg and G. Billen are acknowledged for critically reading the manuscript. The ecosystem model MOSES is available upon request from the authors. It can only be run under the model environment SENECA, which can be purchased from the same authors (price in 1994 US\$100).

\section{References}

Billen, G., 1982. Modelling the processes of organic matter degradation and nutrient recycling in sedimentary systems. In D. B. Nedwell \& C. M. Brown (eds), Sediment microbiology. Academic Press, New York: 15-52.

Billen, G. \& J. Smitz, 1976. Modele mathematique de la qualite de l'eau dans un estuaire partiellement stratifie. In La mecanique des fluides et l'environnement: 1-8.

Billen, G., M. Somville, E. de Becker \& P. Servais, 1985. A nitrogen budget of the Scheldt hydrographical basin. Neth. J. Sea Res. 19: 223-230.

Billen, G., C. Lancelot, E. De Becker \& P. Servais, 1986. The terrestrial marine interface: modelling nitrogen transformations during its transfer through the Scheldt river system and its estuarine zone. In Nihoul, J. C. J. (ed.), Marine interfaces Ecohydrodynamics. Elsevier: 429-490.

Billen, G. \& C. Lancelot, 1988. Modelling benthic nitrogen cycling in temperate coastal ecosystems. In: Blackburn, T. H. \& J. Sorensen (eds), Nitrogen cycling in coastal marine environments. SCOPE. John Wiley \& Sons, Chichester: 341-378.

Billen, G., C. Lancelot, E. De Becker \& P. Servais, 1988. Modelling microbial processes (phyto- and bacterioplankton) in the Schelde Estuary. Hydrobiol. Bull. 22: 43-55.

Billen, G., C. Lancelot \& M. Meybeck, 1991. N, P and Si retention along the aquatic continuum from land to ocean. In R. F. C. Mantoura, J.-M. Martin \& R. Wollast (eds), Ocean Margin Processes in Global Change. John Wiley \& Sons, Chichester: 19-44.

Brock, T. D. \& M. T. Madigan, 1991. Biology of microorganisms. 6th edition. Prentice Hall, Englewood Cliffs: 874 pp.

Brockmann, U., G. Billen \& W. W. C. Gieskes, 1988. North Sea nutrients and eutrophication. In Salomons, W., B. Bayne, E. Duursma \& U. Forstner (eds), Pollution of the North Sea: an assessment. Springer, Berlin: 348-389.

Brockmann, U. H., R. W. P. M. Laane \& H. Postma, 1991. Cycling of nutrient elements in the North Sea. Neth. J. Sea Res. 26: 239-264.

Di Toro, D. M., D. J. O'Connor \& R. V. Thomann, 1971. A dynamic model of the phytoplankton in the Sacramento-San Joaquin Delta. Adv. chem. Ser. 106: 131-150.

Fontugne, M. R. \& J. M. Jouanneau, 1987. Modulation of the particulate organic flux to the ocean by a macrotidal estuary: evidence from measurements of carbon isotopes in organic matter from the Gironde system. Estuar. coast. Shelf Sci. 24: 377-387.

Garber, J. M., 1984. Laboratory study of nitrogen and phosphorus remineralization during the decomposition of coastal plankton and seston. Estuar. coast. Shelf Sci. 18: 685-702.

Gearing, J. N., P. J. Gearing, D. T. Rudnick, A. D. Requejo \& M. J. Hutchins, 1984. Isotope variability of organic carbon in a phytoplankton-based temperate estuary. Geochim. Cosmochim. Acta 48: 1089-1098.

Goreau, T. J., W. A. Kaplan, S. C. Wofsy, M. B. McElroy, F. A. Valois \& S. W. Watson, 1980. Production of $\mathrm{NO}_{2}^{-}$and $\mathrm{N}_{2} \mathrm{O}$ by nitrifying bacteria at reduced concentrations of oxygen. Appl. envir. Microbiol 40: 526-532.

Grasshoff, K., M. Ehrhardt \& K. Kremling, 1983. Methods of seawater analysis. Verlag Chemie, Weinheim, 419 pp. 